\title{
Phosphorus-Containing Flame Retardants from Biobased Chemicals and Their Application in Polyesters and Epoxy Resins
}

\author{
Jacob Sag ${ }^{1}$, Daniela Goedderz ${ }^{1,2}$, Philipp Kukla ${ }^{1}$, Lara Greiner ${ }^{1}$, Frank Schönberger ${ }^{1}$ and \\ Manfred Döring $1, * \mathbb{D}$ \\ 1 Fraunhofer Institute for Structural Durability and System Reliability LBF, D-64289 Darmstadt, Germany; \\ jacob.sag@lbf.fraunhofer.de (J.S.); daniela.goedderz@lbf.fraunhofer.de (D.G.); \\ philipp.kukla@lbf.fraunhofer.de (P.K.); lara.greiner@lbf.fraunhofer.de (L.G.); \\ frank.schoenberger@lbf.fraunhofer.de (F.S.) \\ 2 Ernst-Berl Institute for Chemical Engineering and Macromolecular Science, Technische Universität \\ Darmstadt, D-64287 Darmstadt, Germany \\ * Correspondence: manfred.doering@lbf.fraunhofer.de
}

Academic Editors: Rodolphe Sonnier, Laurent Ferry and Henri Vahabi Received: 30 September 2019; Accepted: 16 October 2019; Published: 17 October 2019

\begin{abstract}
Phosphorus-containing flame retardants synthesized from renewable resources have had a lot of impact in recent years. This article outlines the synthesis, characterization and evaluation of these compounds in polyesters and epoxy resins. The different approaches used in producing biobased flame retardant polyesters and epoxy resins are reported. While for the polyesters biomass derived compounds usually are phosphorylated and melt blended with the polymer, biobased flame retardants for epoxy resins are directly incorporated into the polymer structure by a using a phosphorylated biobased monomer or curing agent. Evaluating the efficiency of the flame retardant composites is done by discussing results obtained from UL94 vertical burning, limiting oxygen index (LOI) and cone calorimetry tests. The review ends with an outlook on future development trends of biobased flame retardant systems for polyesters and epoxy resins.
\end{abstract}

Keywords: biobased polymers; polyester; epoxy resin; flame retardant; phosphorus-containing flame retardants

\section{Introduction}

Regarding the definition of the term "biobased" by IUPAC, a biobased material is comprised partly or wholly of biological products generated from biomass. Biobased materials must not necessarily be biodegradable, biocompatible or environmentally friendly, particularly when they are used to replace their counterpart polymer derived from petrochemical resources [1]. In terms of research and development, a growing interest has emerged of new polymers derived from biobased chemicals or biomass. There is also an increasing interest in a greener synthesis process of flame retardants using sustainable substances or plant-derived chemicals, particularly when considering that petroleum resources are finite. This would also lower the environmental impact. Plant proteins, mainly derived from wheat, soybean and corn or plant oils like soybean, corn and flax oil or plant starches like carbohydrate polymers and cellulose are plant-derived products from renewable sources that can be used neat or modified for the replacement of petrochemicals in certain applications.

Biobased polymers or flame retardants can be made partially or totally from renewable sources. The biobased content in materials is determined by using the standard ASTM D6866-11 test [2] by radiocarbon analysis which quantifies the total organic carbon content in the product. For the utilization 
of substances derived from renewable resources it is imperative to fulfill the following requirements: sustainability, affordability, compatibility and durability [3-5].

Nowadays, there are many processes available for the production of biobased chemicals in biotechnical processes involving the extraction and modification of biomass and fermentation of natural products like sugars or plant material. The development of biobased flame retardant formulations as a whole includes biobased flame retardants and biobased polymer matrices. Engineering plastics like poly(ethylene terephthalate) (PET), poly(butylene terephthalate) (PBT), etc. and biobased polymers like (poly(lactic acid) (PLA) can be produced by using biobased chemicals. Products made from biobased materials are not necessarily biodegradable, particularly when they are chemically modified. Most polymers are known to withstand degradation which is a desirable property, in particular when they are exposed to weathering such as in the case of wind turbine rotor blades, etc. [6,7], but this resistance to degradation is a challenge for biodegradability. Müller et al. reported a depolymerization of PET by using a hydrolase isolated from Thermobifida fusca resulting in water soluble oligomers/monomers [8]. The biodegradability has to be considered in the development of materials produced with biobased materials to generate sustainable materials. Biodegradability and synthesis pathways with biobased materials are still a big challenge in the future, because due to the plant growth there has to be a balance between the application of plant material for food and raw materials for greener solutions. The land use for biobased polymers (PLA, PHA, PTT, PBAT, starch blends, etc.) in 2017 was 672,000 ha which corresponds to $0.005 \%$. The global agricultural area requires 5 billion ha (3.65\%). An increase up to $1,038,000$ ha $(0.008 \%)$ is predicted by IfBB for biobased polymers in $2022[3-5,9]$.

Biobased polymers include all polymers which are made of renewable biosources resulting in biodegradable or non-biodegradable biobased polymers. The biobased non-biodegradable part of biopolymers still represent a greater part of the biobased polymers production capacity in 2017 and there will be a slight change until 2022 (Figure 1). The main part of biobased non-biodegradable biobased polymers is represented by bio-PET derived from plant material. The Coca-Cola Company developed the PlantBottle, which is a blend of plant-derived material (up to 30\%) and petrochemical material in 2009 [10,11]. PLA use as a biodegradable polyester will rise from $10.5 \%$ in 2017 to $18.7 \%$ in $2022[9]$.

\section{Biobased polymer production capacities by material type}

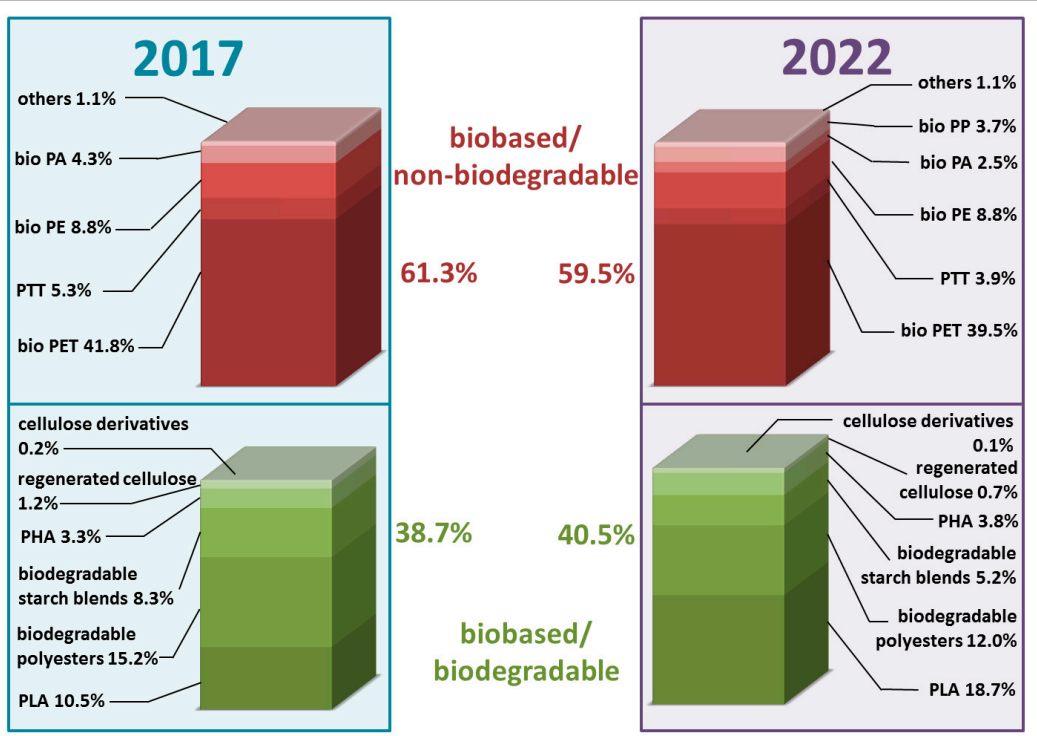

Figure 1. Biobased polymer production capacities for 2017 and 2022 by material type (source: IfBB 2018 [9]). 
Table 1 summarizes selected chemical building blocks which can be produced by a biotechnical process for certain applications [12,13]. Combustible plastics which are near electrical or heat sources require flame retardant solutions. Due to the development of electric mobility in the last years and limited petrochemical resources biobased polymers will be one of the target materials for the future in this and other segments. Biobased polymers and biobased flame retardants have a huge potential for greener polymer synthesis and flame retardant solutions and contribute to a reduced environmental impact in this context. This review covers biobased phosphorus-containing flame retardants for epoxy resins and polyesters. The application range of polyesters includes synthetic fibers [14] in home furnishing or car upholstery and foams in construction materials like wind turbine blades [15]. Their resistance to stretching, most chemicals and wrinkling are characteristics of polyesters which make them very interesting for the textile industry [16]. Polyesters, which are made of renewable raw materials and are biodegradable, represent a greener solution in terms of sustainability than biopolyesters which are not biodegradable. Certain polyesters possess biodegradability from the outset like PLA or PBS and can be produced with renewable resources. The consideration of the life cycle assessments (LCA) and the comparison between petroleum based polyesters and biobased polyesters also includes the evaluation of the environmental profile regarding emissions during the production process or the agriculture operations of the raw material extraction. As long as the comparison of the life cycle assessment is not favorable regarding environmental aspects, a biobased polymer implicates no superiority to its petrochemical based derivative. Chen et al. worked out the life cycle assessment of petroleum and biobased PET bottles [17].

Epoxy resin systems form thermosets by crosslinking of multifunctional epoxy monomers and curing agents. Since their properties, like mechanical properties, chemical resistance, low cost, relative low curing shrinkage [18,19] are exterior to other materials, they are used in many different applications like coatings, composites or high performance materials $[20,21]$. The most common epoxy resin is bisphenol A diglycidyl ether (DGEBA), which is synthesized from bisphenol A (BPA) and epichlorohydrin [22]. For epichlorohydrin, a synthetic route from glycerin as a renewable source is economically viable [23], but there is no similar route for BPA [24]. Another disadvantage of DGEBA-based epoxy resins is their flammability [25]. Therefore, there is put much effort in finding new flame retardant agents for epoxy resins based on green chemicals. There are reactive flame retardants, that are incorporated into the network by preformulation reaction or throughout the curing process, and non-reactive flame retardants. Reactive flame retardants with two or more reactive groups operate as a hardener or as a resin [26,27] as an additional feature. Non-reactive flame retardants can be multifunctional improving mechanical, thermic, electric and other properties [28-31].

Table 1. Biobased monomers and chemical building blocks for the synthesis of biobased polymers.

\begin{tabular}{cccc}
\hline $\begin{array}{c}\text { Monomer/Chemical } \\
\text { Building Block }\end{array}$ & Biotechnical Process & Application & Reference \\
\hline Adipic acid & $\begin{array}{c}\text { Fermentation of glucose }+ \\
\text { hydrogenation of cis,cis-muconic } \\
\text { acid or glucaric acid }\end{array}$ & $\begin{array}{c}\text { Resins, polyesteramines, } \\
\text { polyesterurethanes }\end{array}$ & {$[13,32-34]$} \\
\hline 1,4-butanediol & $\begin{array}{c}\text { Fermentation of sugars, } \\
\text { hydrogenation of succinic acid }\end{array}$ & PBAT, PBS, PBT & {$[13,34,35]$} \\
\hline Benzaldehyde & Steam distillation & Resins, flame retardants & {$[36,37]$} \\
\hline Benzene, toluene, xylene (BTX) & Pyrolysis of lignocellulose residues & Building block for PET & {$[12,38]$} \\
\hline Cardanol & $\begin{array}{c}\text { Extraction from cashew nuts via hot } \\
\text { oil or roasting process, distillation }\end{array}$ & Resins & {$[18,20,39]$} \\
\hline
\end{tabular}


Table 1. Cont

\begin{tabular}{|c|c|c|c|}
\hline $\begin{array}{l}\text { Monomer/Chemical } \\
\text { Building Block }\end{array}$ & Biotechnical Process & Application & Reference \\
\hline Ethylene glycol & $\begin{array}{l}\text { Ethanol dehydration, } \\
\text { hydrogenolysis of xylitol, } \\
\text { sorbitol or glycerol }\end{array}$ & PET, PEF & {$[13,38]$} \\
\hline Eugenol & Extraction from Dianthus & Resins & [40-42] \\
\hline 2,5-Furandicarboxylic acid & $\begin{array}{l}\text { Fermentation, dehydration of } \\
\text { fructose/glucose, oxidation }\end{array}$ & $\begin{array}{c}\text { PEF, PBF, } \\
\text { polyesterurethanes }\end{array}$ & {$[13,43]$} \\
\hline Isobutanol & Yeast fermentation of sugars & $\begin{array}{l}\text { PET (production of } \\
\text { terephthalic) }\end{array}$ & {$[12,13]$} \\
\hline Isosorbide & Sorbitol dehydration & Thermosetting resins & {$[13,44]$} \\
\hline Itaconic acid & Fermentation of carbohydrates & $\begin{array}{l}\text { Photocurable precursors, } \\
\text { plasticizers, resins, flame } \\
\text { retardants }\end{array}$ & {$[13,45,46]$} \\
\hline Lactic acid & Fermentation & PLA & {$[13,47,48]$} \\
\hline Levullinic acid & Acid hydrolysis of lignocellulose & PBS & {$[13,49,50]$} \\
\hline Lignin & Plant biomass & $\begin{array}{l}\text { Resins, PET, Flame } \\
\text { retardant agents }\end{array}$ & [51-55] \\
\hline Malic acid & fermentation & $\begin{array}{l}\text { Functionalized chiral } \\
\text { polyesters }\end{array}$ & {$[13,56]$} \\
\hline Myrcene & $\begin{array}{l}\text { Extraction from essential oils, } \\
\text { pyrolysis of } \beta \text {-pinene }\end{array}$ & $\begin{array}{l}\text { Resins, Polyesters, } \\
\text { Polymyrcene }\end{array}$ & [57-59] \\
\hline p-Benzoquinone & $\begin{array}{c}\text { Microbial catalysis of glucose, } \\
\text { oxidation }\end{array}$ & Resins & {$[60,61]$} \\
\hline Phloroglucinol & Extraction of seaweeds & Resins & {$[62,63]$} \\
\hline Phytic acid & Extraction from beans & Flame retardant & [64-66] \\
\hline 1,3-Propanediol & Fermentation & $\begin{array}{l}\text { PTT, fibers, elastomers, } \\
\text { polyesterurethanes }\end{array}$ & {$[12,13,67]$} \\
\hline Sebacic acid & Caustic fusion from castor oil & Polyesters, Resins & {$[68,69]$} \\
\hline Sorbitol & Fermentation and hydrogenation & $\begin{array}{l}\text { Functional polyesters, } \\
\text { coatings }\end{array}$ & {$[13,70,71]$} \\
\hline Succinic acid & Fermentation of sugars & $\begin{array}{l}\text { Textiles, coatings, } \\
\text { PBS, PBT }\end{array}$ & {$[13,49,72]$} \\
\hline Tartaric acid & Precipitation in wine production & $\begin{array}{l}\text { Polyester, flame } \\
\text { retardant }\end{array}$ & {$[73,74]$} \\
\hline Terephthalic acid & Isobutylene oxidation, fermentation & PET, coatings & {$[12,13,75,76]$} \\
\hline Vanillin & Oxidation of lignin & Resins, polyvanillin & {$[77,78]$} \\
\hline
\end{tabular}

(PBAT (poly(butylene adipate terrephthalate), PBS (poly(butylene succinate), PBT (poly(butylene terephthalate), PET (poly(ethylene terephthalate), PEF (poly(ethylene furanoate)), PBF (poly(butylene 2,5-furandicarboxylate), PLA (poly(lactic acid), PTT (poly(trimethylene terephthalate)) and flame retardants.

\section{Synthesis of Phosphorus-Containing Biobased Flame Retardants}

There are different biobased materials which possess no suitable flame retardant efficiency by themselves, but a chemical modification can lead to a potential flame retardant agent. For example, biobased alcohols like isosorbide, pentaerythritol, vanillin, cardanol, eugenol, glycerol, etc. or double bond-containing structures like itaconic acid (IA) are starting materials which can be obtained from biomass. This chapter summarizes different phosphorylation methods for the synthesis of phosphoruscontaining flame retardants used for polyesters and epoxy resins. The major part of the phosphorylating agents is not biobased, but the final flame retardant product has an increased biobased ratio due to the phosphorylation of biobased starting materials. 


\subsection{Biobased Flame Retardants for Poly (Lactic Acid)}

One of the most used biobased chemicals for the synthesis of "green" flame retardants is pentaerythritol (PER, Scheme 1). It can be synthesized by conversion of acetaldehyde with formaldehyde, which both can be produced from biomass-to-liquid (BtL) process or carbon monoxide hydrogenation [79]. PER is often used in intumescent flame retardant systems (IFR) as a carbonization agent along an acid source and a blowing agent [80-82]. For the best synergistic effect between the components which are required for intumescence, various research groups combined them into one molecule. Tao et al. synthesized a phosphazene cyclomatrix network polymer poly(cyclotriphosphazene-co-pentaerythritol) (PCPP I, Scheme 1) using PER and hexachlorocyclo-triphosphazine (HCCP). A high char residue $(68 \mathrm{wt} \%)$ at $600^{\circ} \mathrm{C}$ after thermogravimetric analysis indicates that PCPP is an efficient char forming agent [83].

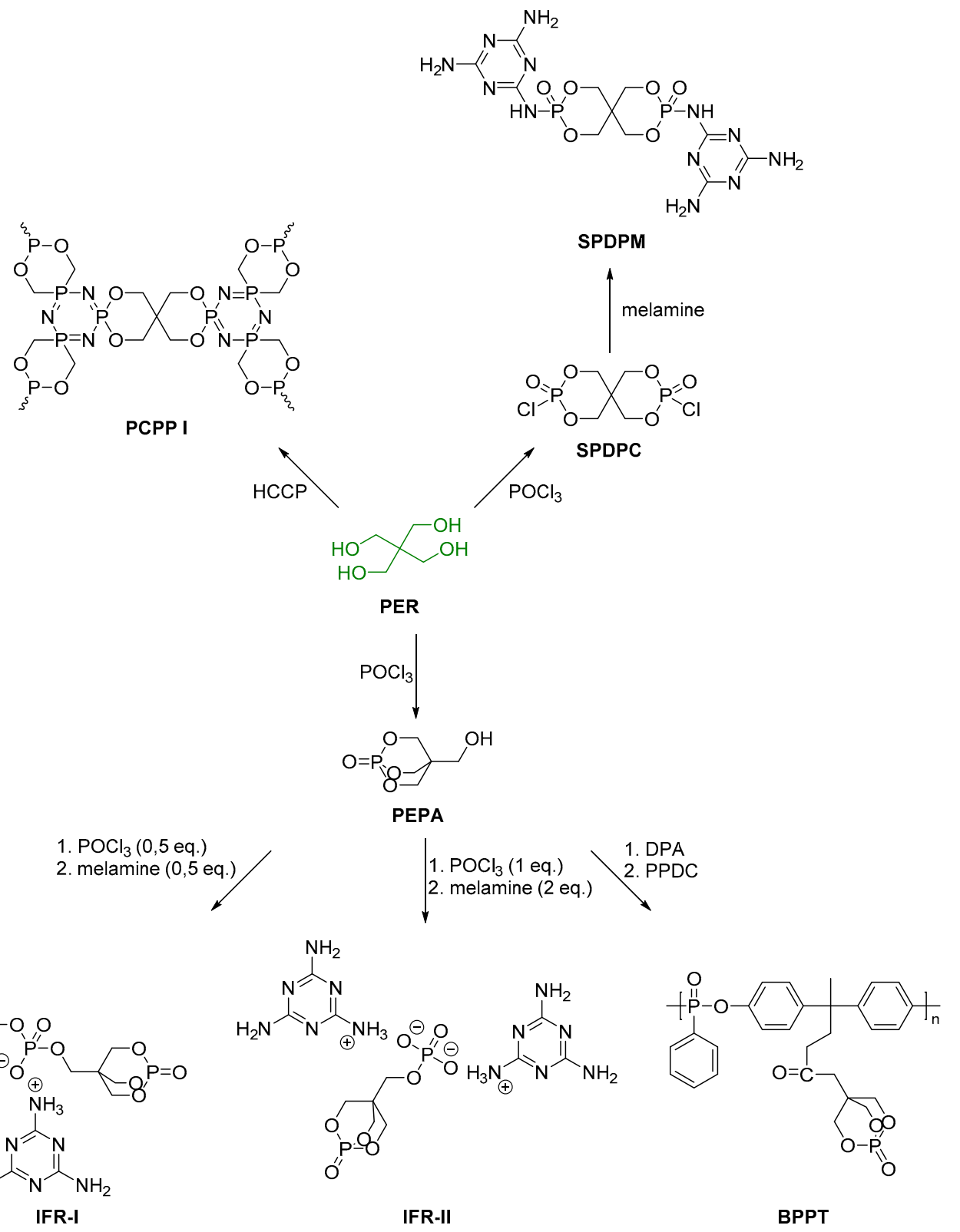

Scheme 1. Flame retardants derived from PER.

Zhan et al. [34] reported the synthesis of spirocyclic pentaerythritol bisphosphorate diphosporyl melamine (SPDPM) from spirocyclic pentaerythritol (SPDPC, Scheme 1) and melamine. After 
decomposition, SPDPM possesses high char residues $(40 \mathrm{wt} \%)$ at $600{ }^{\circ} \mathrm{C}$ [84]. Xuan et al. synthesized the PER derived caged bicyclic pentaerythritol phosphate alcohol (PEPA, Scheme 1) for novel intumescent flame retardants, IFR-I and IFR-II (Scheme 1). Similar to other systems, TGA results of IFR-I showed a high residue percentage of $45 \mathrm{wt} \%$ at $600{ }^{\circ} \mathrm{C}$ [85]. Jing et al. described the synthesis of another PEPA based flame retardant using diphenolic acid, which can also be derived from biomass [86,87]. TGA data of the novel biobased polyphosphonate (BPPT, Scheme 1) showed a residue weight of $41 \mathrm{wt} \%$ at $600^{\circ} \mathrm{C}$.

Further flame retardants derived from biobased chemicals were synthesized by Lin et al. and Zhao et al. using 1,2-propanediol and vanillin (Scheme 2a,b). The TGA curves of both compounds indicate a flame retardant action mainly in the gas phase $[88,89]$. Wang et al. synthesized an inherently flame retarded PLA (PPLA I, Scheme 2c) via-chain extending reaction of dihydroxyl terminated pre-poly(lactic) acid (Pre-PLA, Scheme 2c) with ethyl phosphordichloridate and melt blended it with PLA [90]. Another intrinsically phosphorus-containing PLA (PPLA II, Scheme 2d) was synthesized by Yu et al. using L-lactide, P-DDS-Ph and hexamethylene diisocyanate (HDI) (Scheme 2d) [91].

a)<smiles>COc1ccc(C=O)cc1OC</smiles>

b)<smiles>CC(O)COCC(=O)CCP(=O)(CCC(C)(C)C)c1ccccc1</smiles>

c)

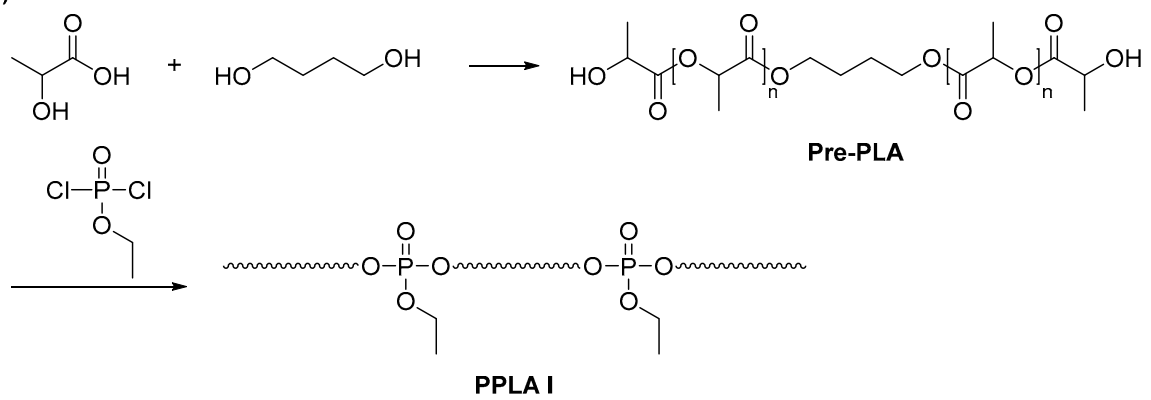

d)<smiles>CC1OC(=O)C(C)OC1=O</smiles>

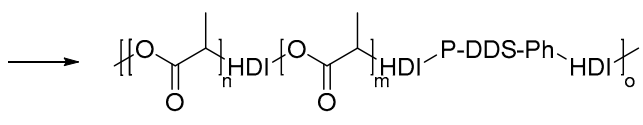

PPLA II

Scheme 2. Flame retardants based on (a) vanillin, (b) 1,2-propanediol and (c and d) PLA. 


\subsection{Biobased Flame Retardants for Poly (Ethylene Therephthalate) and Poly (Butylene Succinate)}

Besides isomannide and isoidide, isosorbide as 1,4,3,6-dianhydrohexitol can be obtained from starch via glucose as intermediate. The synthesis of isosorbide from starch requires an enzymatic process degrading the starch into D-glucose and D-mannose. D-Glucose is hydrogenated into D-sorbitol which can be dehydrated to isosorbide (Scheme 3). In a similar way, isomannide is obtained from D-mannose via D-mannitol [92-94].

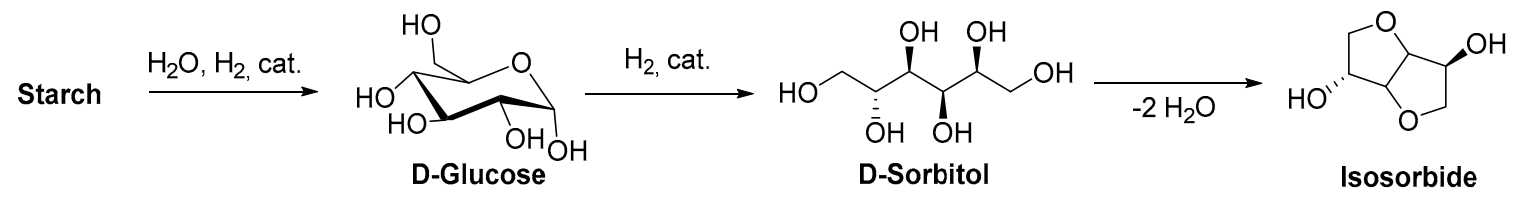

Scheme 3. Synthesis of isosorbide from starch via D-glucose and D-sorbitol.

The phosphorylation towards bis-phosphorus esters can be done by a nucleophilic substitution with the phosphorus chlorides or by Atherton-Todd reaction with 9,10-dihydro-9-oxa10-phospha-phenanthrene-10-oxide (DOPO, Scheme 4) [95]. Different phosphorus modified isosorbide-containing flame retardants were analyzed in PLA [96] and PBS [97].

$\mathrm{Hu}$ et al. used phenylphosphoric dichloride, dichlorophenylphosphate, diphenylphosphate chloride, diphenylphosphoric chloride and DOPO as phosphorous compounds resulting in different chemical environments of the phosphorous atom in the flame retardant. A mass loss of $2 \%$ can be observed in the range of $289-321^{\circ} \mathrm{C}$ in nitrogen atmosphere for all phosphorus-containing isosorbide flame retardants [97,98].

Lignin is a phenol-containing cross-linked biomacromolecule that can be isolated by two different extraction procedures (alkali and organosolv). The flame retardant efficiency of neat lignin is already known for different polymer systems [51,52,99]. Ferry et al. compared the fire behavior of lignin obtained from different extraction procedures in PBS. The two lignin types differentiate in the decomposition temperature; organosolv lignin has a $30{ }^{\circ} \mathrm{C}$ higher decomposition temperature in the first decomposition step $\left(349^{\circ} \mathrm{C}\right)$. Three main decomposition steps are taking place during the decomposition of lignin. In the first step $\left(230-260^{\circ} \mathrm{C}\right)$, the release of low molecular weight products of a propanoid side chain cleavage takes place. The second step is the main degradation step $\left(275-450^{\circ} \mathrm{C}\right)$ where large amounts of methane are released. The formation of char and the release of dihydrogen take place above $500{ }^{\circ} \mathrm{C}$. Ferry et al. compared the two neat lignins also by using cone calorimetry. By using a grafting onto process, lignin can be modified with phosphorous compounds and the flame retardant efficiency can be enhanced [53].

Itaconic acid is a biobased monomer which can be used for the production of aliphatic esters containing DOPO and can be gained by the fermentation of sugars. There is a growing market of itaconic acid due to the versatility of this unsaturated trifunctional diacid. It can be converted to polyamides with diamines, polyesters with diols, polyitaconic acid or polyacrylates with methacrylic acid derivatives [100]. Pospiech et al. developed different linear aliphatic polyesters with biobased contents up to $100 \%$ containing itaconic acid. An increasing DOPO monomer content leads to an increasing glass transition temperature. The obtained polyesters (Scheme 5) were compared to PET, PTT and PBT by using pyrolysis combustion flow calorimeter (PCFC), also called microscale combustion calorimeter (MCC) [101,102]. 


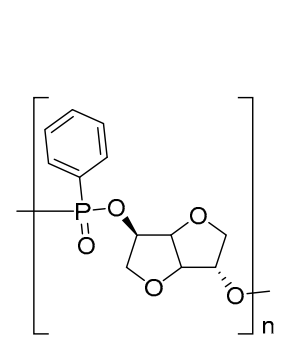

polyphenylphosphonate isosorbide (PPPI)

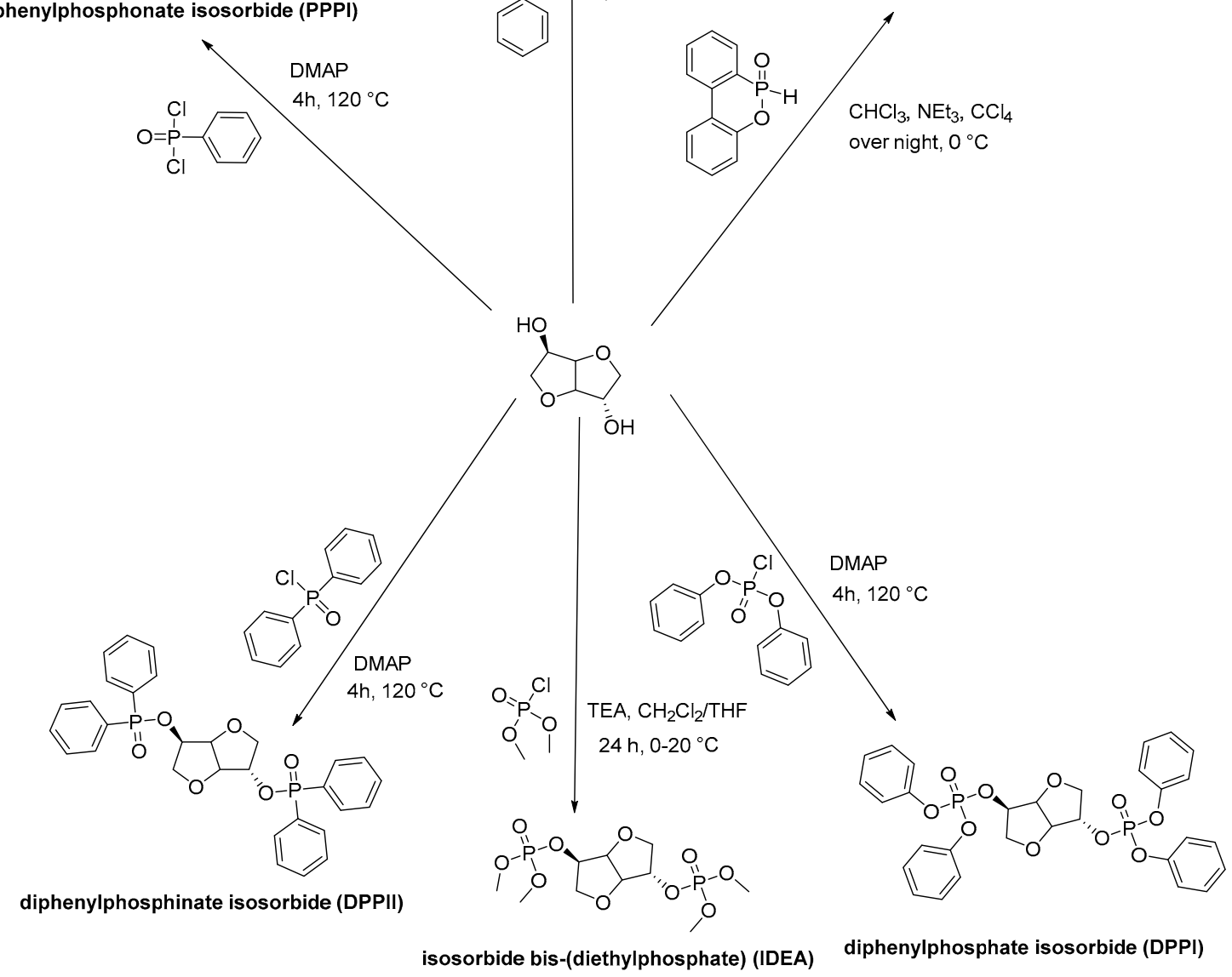

Scheme 4. Phosphorylation of isosorbide with different phosphorus-containing compounds (DMAP: 4-dimethylaminopyridine).
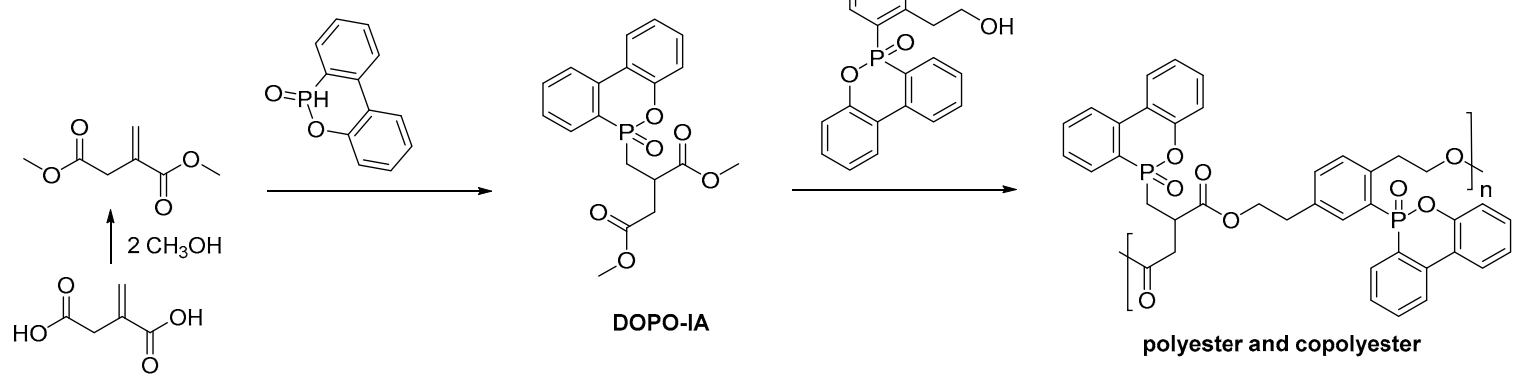

Scheme 5. Itaconic acid as building block for flame retardant polyester or copolyester.

Glycerol is a trifunctional alcohol which can be modified in a two-step process resulting in a star shaped highly thermostable DOPO-containing glycerol triacrylate (GL-3DOPO, Scheme 6) by using acryloyl chloride. The decomposition of GL-3DOPO starts at $360^{\circ} \mathrm{C}$ in nitrogen atmosphere and at $368^{\circ} \mathrm{C}$ in air atmosphere. Xie et al. melt blended GL-3DOPO with engineering plastics like PET, PBT, 
PA6, PA66 and PC. GL-3DOPO decreased the melting temperature and the glass transition temperature of the melt blended polymers [103].<smiles>C=CC(=O)OCC(COC(=O)C=C)OC(=O)C=C</smiles>

Scheme 6. Synthesis of DOPO-containing glycerol triacrylate.

Phosphorus chlorides or P-H-compounds can be used for phosphorylations within the context of Atherton-Todd reactions, whereas the latter requires carbon tetrachloride as chlorinating agent. In terms of green chemistry, carbon tetrachloride can be replaced by $N$-chlorsuccinimide resulting in succinimide as byproduct. By using $N$-chlorsuccinimide as chlorinating agent, flame retardant synthesis of DOPO-PEPA (Scheme 7) is more sustainable than using carbon tetrachloride. DOPO-PEPA is used as flame retardant in PET [104,105], PBT [104] and epoxy resins [104,106].<smiles>O=[PH](=O)(O)Oc1cccc2c1op(O)oc1ccccc12</smiles>
DOPO

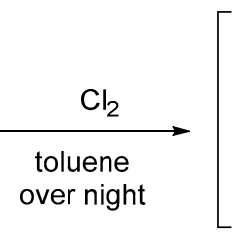

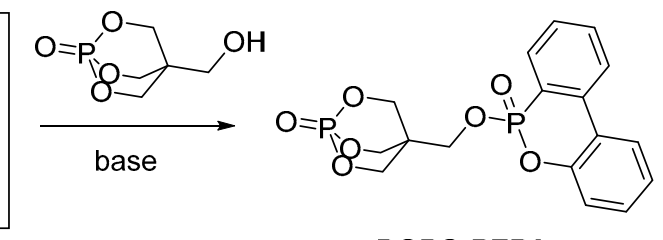

DOPO-PEPA

Scheme 7. Synthesis of DOPO-PEPA.

Deoxyribonucleic acid (DNA, Figure 2) is a biomacromolecule and provides a source of acid by the phosphate group. The deoxyribose moiety has high carbon content and the nitrogen containing bases have an effect as blowing agent. In sum DNA is a good basis for an intumescent flame retardant system. DNA revealed as a suitable flame retardant for surface treated cotton fabrics, PET foams and bulk samples of different polymers [105,107-111]. A DNA containing coating provides a physical barrier through the formation of a carbon-rich protective shield when exposed to a heat source [112].

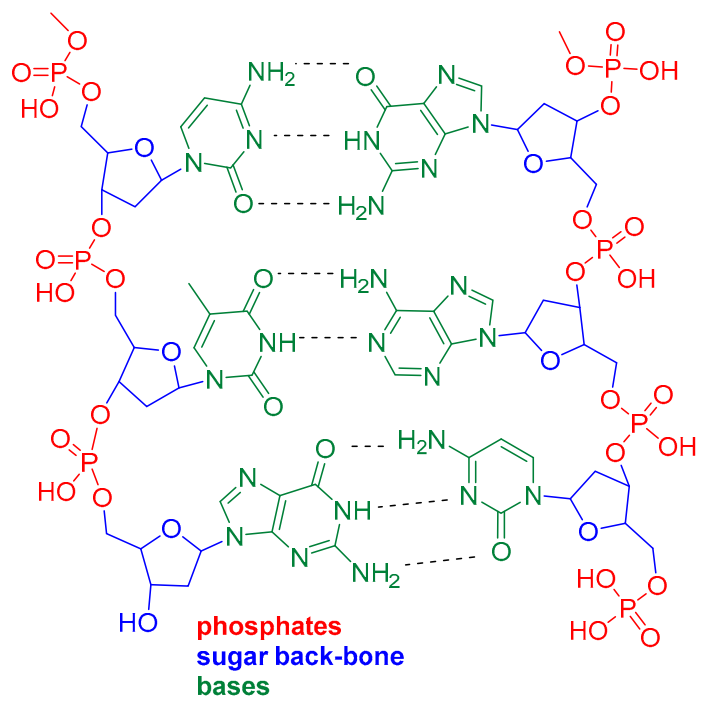

Figure 2. Chemical structure of DNA with phosphates (red), bases (green) and the sugar backbone (blue). 
Milk contains casein as phosphorus-based proteins which are mainly used as food ingredient. Caseins possess high phosphorus content due to seryl-phosphate groups or phosphoserine groups depending on the components of the casein. The fire behavior of cotton, polyester or fabrics containing blends of both with deposited casein was investigated by Alongi and Carosio et al. Casein promotes the polyester cyclization and the char formation resulting in a protective layer [112-114].

\subsection{Biobased Flame Retardants for Epoxy Resin Systems}

\subsubsection{Reactive Flame Retardant Epoxy Monomers}

Animal testing has revealed that BPA has negative effects on reproduction and neurobehavioral effects, a potential to favor cancer and metabolic disorders in small dosages as well as other negative effects at high dosages [115-117]. Many research groups have tried to find a new, renewable raw material for epoxy resins [118], but also intrinsic flame retardant, biobased epoxy resins are developed based on eugenol [40,119], daidzein [120] components of soybeans [121], furan derivatives [40], itaconic acid [45,122] or pentaerythritol [123]. Another approach is incorporating flame-retardant silicon- [124] or phosphorus- [45] containing groups into the backbone as substituents in epoxy resins or curing agents [48]. Flame retardant epoxy resins are typically synthesized by:

- incorporation of phosphorus-containing groups into an epoxide component or

- incorporation of phosphorus-containing groups into a molecule with a following epoxidation of unsaturated side chains.

Ménard et al. [62] introduced epichlorohydrin to the biobased phloroglucinol (benzene-1,3,5-triol) developing a trifunctional molecule, shown in Scheme 8. The zinc chloride catalyzed oxirane ring opening reaction with triethyl phosphate leads to a flame retardant monomer (P2EP1P, Scheme 8).

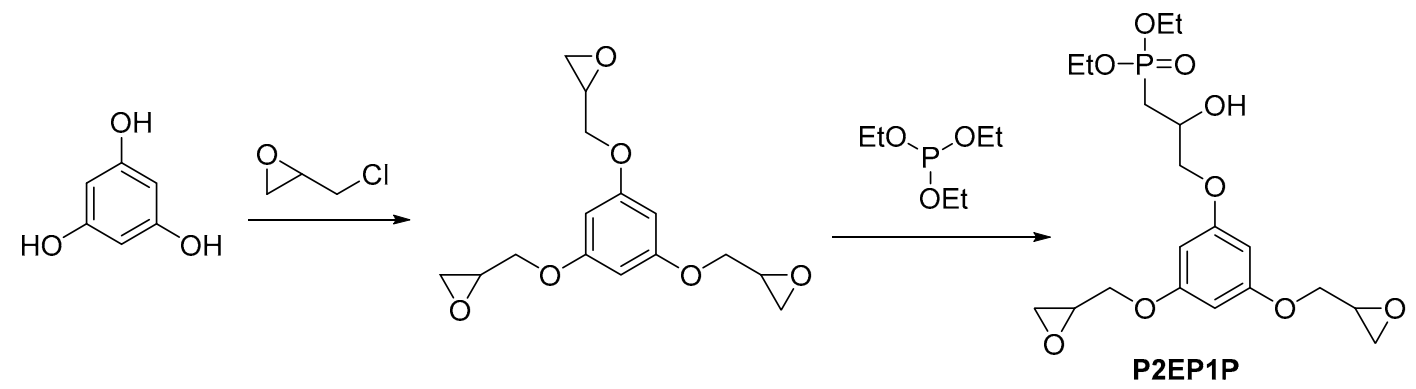

Scheme 8. Synthesis of the reactive, flame retardant monomer diglycidyl monophosphate phloroglucinol (P2EP1P).

Ma et al. [45] used a catalyzed reaction to add 9,10-dihydro-9-oxa-10-phosphaphenanthren-10-oxide (DOPO) to the double bond of itaconic acid. They determined two synthetic routes to obtain epoxides, shown in Scheme 9. The direct epoxidation with epibromohydrin (Scheme 9b) leads to the same product (EADI) with slight lower yield than the esterification with allyl bromide followed by an oxidation with a peroxide like meta-chloroperbenzoic acid (Scheme 9a).

Lligadas et al. $[60,125]$ esterified a phosphorus containing molecule (DOPO-HQ) with biobased 10-undecenoyl chloride followed by epoxidation the terminal double bond, shown in Scheme 10. This leads to the phosphorus-containing flame retardant DOPO-III. The starting compound DOPO-HQ is synthesized by the addition of DOPO to $p$-benzoquinone. 
<smiles>C=CCOC(=O)CC(COP(=O)(O)O)C(=O)OCC=CC(=O)OCC(CC(=O)O)C(=O)OCC1CO1</smiles>

Scheme 9. Synthesis of the reactive, itaconic acid based flame retardant monomer (EADI).<smiles>O=P(O)(O)Oc1cc(O)ccc1O</smiles><smiles>C=CCC(C)C(=O)Cl</smiles><smiles>[R6]O[Na]</smiles><smiles>O=C(CC1CO1)Oc1ccc(OC(=O)CC2CO2)c(OP(=O)(O)O)c1</smiles>

DOPO-III

Scheme 10. Synthesis of the reactive, flame retardant monomer 10-[2',5'-bis(9-oxiranyl-nonayloxy) phenyl]-9,10-dihydro-9-oxa-10-phosphaphenanthrene-10-oxide (DOPO-III).

Caillol et al. [41] analyzed different biobased starting materials for flame retardant epoxides. Cardanol or eugenol and phosphoryl chlorides undergo a condensation reaction with $\mathrm{HCl}$ as condensate, shown in Scheme 11. Eugenol is a phenylpropanoid, which can be obtained from clove oil, but different plants like sweet basil produce eugenol as well [126]. Depending on the quantity of functional groups in the phosphorus-containing derivative, two or three eugenol molecules are linked leading to two or three epoxide functional groups after epoxidation. The reaction pathway and the products TEEP, DEEP and DEEP-Ph are shown in Scheme 11.

n<smiles>[X]C(=O)c1ccccc1</smiles><smiles>[X][PH](=O)(Oc1ccc(CC=C)cc1OC)Oc1ccc(CC=C)cc1OC</smiles>

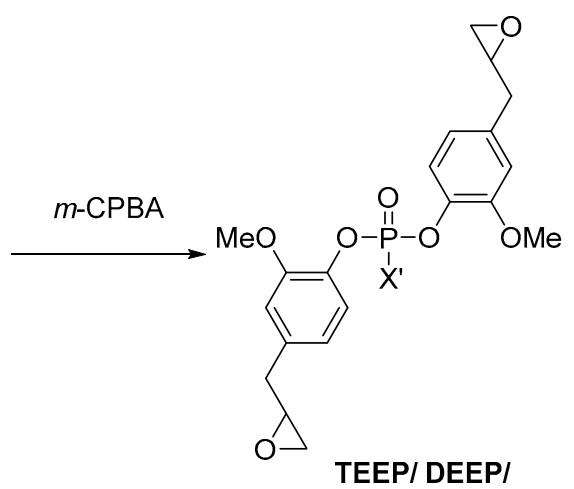

DEEP-Ph

Scheme 11. Synthesis of the reactive, eugenol based flame retardant monomers TEEP $(\mathrm{X}=\mathrm{Cl}, n=3)$, $\operatorname{DEEP}(\mathrm{X}=\mathrm{OPh}, n=2)$, DEEP-Ph $(\mathrm{X}=\mathrm{Ph}, n=2)$. 
Cardanol, on the other hand, being non-edible and a by-product of the cashew industry, is a promising source for phenolic oils [127]. Consequently, different approaches to use cardanol have been examined, like the usage as fuel [128], process chemical $[129,130]$ or raw material for special chemicals [131,132]. Cardanol does not have a defined number of double bonds, it can vary between 0 and 3. Therefore, the number of epoxy groups can vary with the same reaction route. Furthermore, the epoxidation agent hydrogen peroxide reacts partially with terminal double bonds [41]. The reaction of cardanol and phosphoryl trichloride followed by epoxidation led to the flame retardant TECP shown in Scheme 12.

3

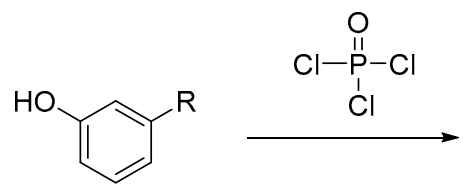

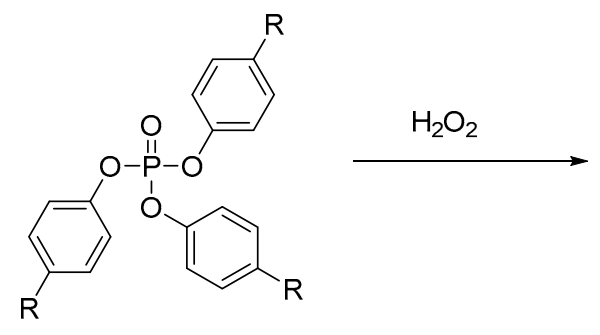

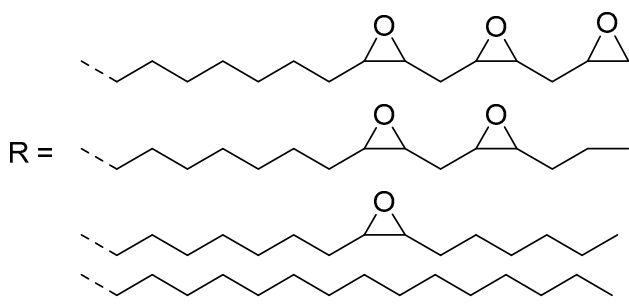

Scheme 12. Synthesis of the reactive, cardanol based flame retardant monomer TECP.

\subsubsection{Reactive Flame Retardant Curing Agents}

Not only epoxy resins, but also curing agents can be modified. As there is a broad range of different phosphorus-containing hardeners (e.g., by Toldy et al. [133]), we will focus on biobased hardeners containing DOPO.

In general, DOPO reacts with benzaldehyde in a Pudovik-type reaction by electrophilic addition [134]. After hydrolysis of the secondary hydroxyl group, a nucleophile can react with the transient carbocation via nucleophilic addition and deprotonation. Dai et al. [135] combined the DOPO-adduct of 4-hydroxybenzaldehyde and aniline to incorporate nitrogen to the flame retardant (DOPO-PHM, Scheme 13). Lin et al. [136] compared the reactivity of the DOPO-adducts of vanillin and acetovanillone under alkaline condition adding phenol after hydrolysis. This reaction path is not suitable for vanillin since the secondary carbocation is not stabilized for further reactions. The resulting bisphenolic structure with acetovanillone (hydroxyl PES, Scheme 13) can be modified by ring closing reactions with furfurylamine and paraformaldehyde. This reaction and the flame retardant benzoxazine are shown in Scheme 14. These benzoxazines have up to six different possible reactive sites [137]. Liu et al. [36] added DOPO to terephthaldicarboxaldehyde and the adduct TDCA-DOPO was polymerized with phenol to a novolac compound (Ar-DOPO-N, Scheme 13), that is suitable as flame retardant in novolac epoxy resins. This reaction path was also used by Wang et al. [138] for their synthesis of TDCA-DOPO. Then it was condensed with SPDPC leading to PFR (Scheme 15). 
<smiles>O=Cc1ccc(O)cc1</smiles>

4-Hydroxybenzaldehyde<smiles>O=POC(O)c1ccc(O)cc1</smiles><smiles>Nc1ccccc1</smiles>

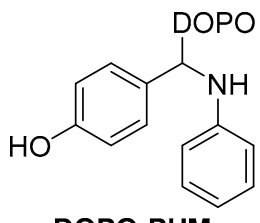

DOPO-PHM<smiles>Oc1ccccc1</smiles>

Acetovanillone<smiles>O=Cc1ccc(C=O)cc1</smiles>

Terephthaldicarboxaldehyde<smiles>COc1cc(C(C)[Po+][O-])ccc1O</smiles><smiles></smiles>

TDCA-DOPO<smiles>[2H]C([2H])(c1ccc(O)cc1)c1ccc(O)c(OC)c1</smiles><smiles></smiles>

Ar-DOPO-N<smiles>Oc1ccccc1</smiles>

Scheme 13. Synthesis of flame retardant curing agents DOPO-PHM, hydroxyl-PES and Ar-DOPO-N.<smiles>[R]c1cc(C(C)([18OH])c2ccc(O)c([R2])c2)ccc1O</smiles> 
To obtain a flame retardant pressure-sensitive adhesive material (PSA), Wang et al. [69] modified DOPO-HQ with ethylene spacers [140] and used a polycondensation reaction with a prepolymeric ester from sebacic acid, yielding a polymeric hardener shown in Scheme 17.<smiles></smiles><smiles>O=C(O)C(=O)OCCOc1ccc(OCCO)c(O[Po](=O)[O-])c1</smiles><smiles>O=C(O)C(=O)OCCOc1ccc(OCCOC(=O)C(=O)O)c(O[O+])c1</smiles>

Scheme 17. Synthesis of the prepolymeric ester from sebacic acid.

\subsubsection{Non-Reactive Flame Retardants}

Multifunctionality is not limited to flame retardant hardeners or epoxy resins. For flame retardants, several different functionalities are reported, like anti-aging [141], synergistic [142], nano-filler [143], toughening [18] or fiber protection [21] effects.

The reactivity of oxirane groups can be used to add different functional groups. For example, Hu et al. [18] combined TECP (the phosphate of cardanol after epoxidation) and DOPO, shown in Scheme 18. The resulting non-reactive flame retardant acts additionally as a toughening agent in epoxy resins.<smiles>[R]c1ccc(OP(=O)(Oc2ccc([R])cc2)Oc2ccc([R])cc2)cc1</smiles>

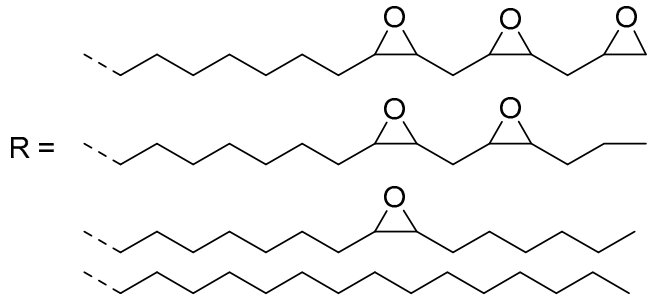

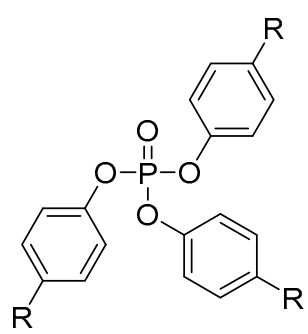

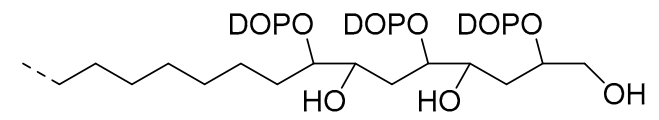

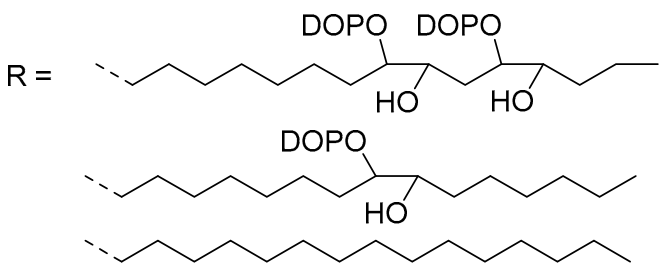

Scheme 18. Functionalization of TECP with DOPO.

Wang et al. [143] synthesized nano-filler flame retardants from phytic acid by a hydrothermal method. Phytic acid (see Scheme 19) is a phosphorus reservoir that acts as antioxidant for plants like grains or beans [144]. It was converted with melamine to the curing agent PAMA. Another approach are inclusion complexes that show better flame retardant efficiency. Zhao et al. [145] combined cyclodextrine, a degradation product of starch, as charring agent and $N, N^{\prime}$-diamyl-p-phenylphosphonicdiamide (P-MA, synthesized from amilamine see Scheme 20) as an acid source [146]. 


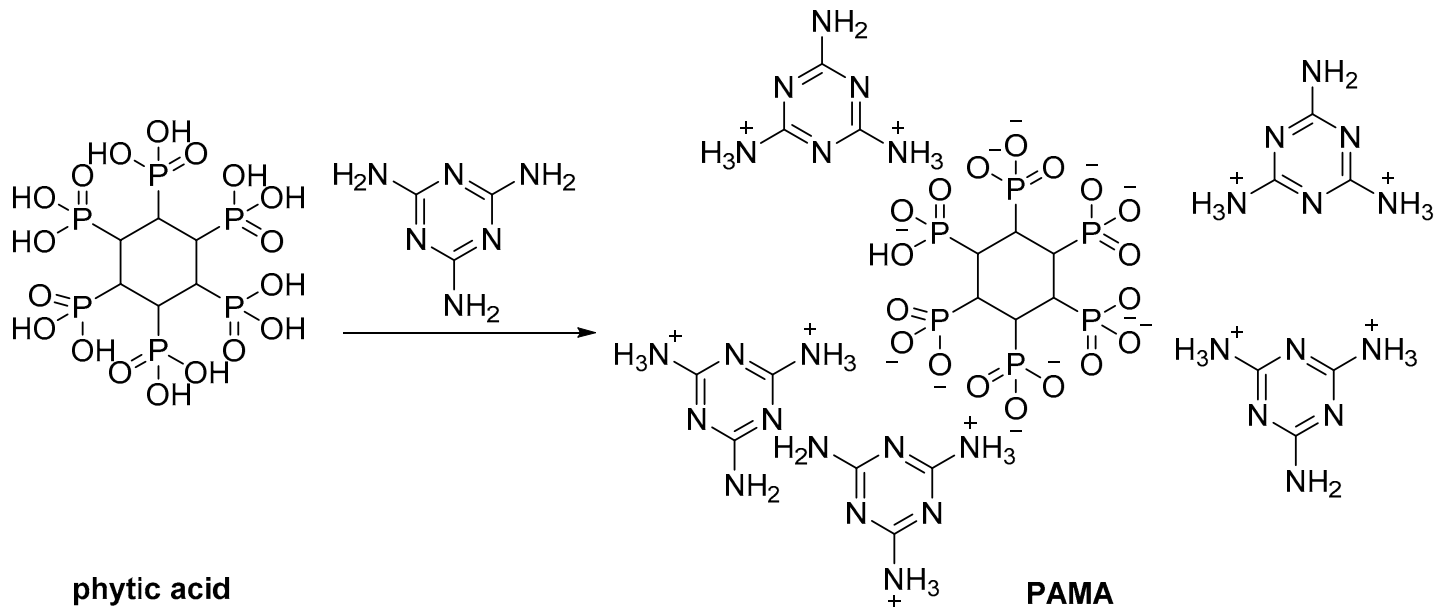

Scheme 19. Synthesis of phytic acid based flame retardant PAMA.<smiles>CCCCCN</smiles><smiles>CCCCCNP(=O)(NCCCCC)c1ccccc1</smiles>

P-MA

Scheme 20. Synthesis of amylamine based flame retardant P-MA.

There are other promising biobased systems, which need to be tested for flame retardancy. Fache et al. synthesized epoxy monomers from lignin [54,147]. Different research groups have developed biobased flame retardants without determining other applications. Jin et al. added DOPO twice to acrolein achieving V-0 at $3 \mathrm{wt} \%$ flame retardant content in DGEBA/DDM (Scheme 21a) [148]. Acrolein is available from biobased alcohols via dehydration [149]. Via Atherton-Todd phosphorylation, Howell and Sun [150] combined diethyl tartrate and DOPO to DT-DOPO, shown in Scheme 21b. Tartrate precipitates as insoluble salts in wine production [74].

a)<smiles>C=CC=O</smiles>

b)<smiles>CCOC(=O)C(O)C(O)C(=O)OCC</smiles>

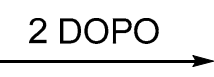<smiles></smiles>

ABD<smiles></smiles>

DT-DOPO

Scheme 21. Synthesis of the acrolein (a) and tartrate (b) based flame retardant diethyl 6,6'-(1hydroxypropane-1,3-diyl)bis(dibenzo[c,e][1,2]oxaphosphinine 6-oxide) (ABD) and 2,3 didopyloxybutanedicarboxylate (DT-DOPO).

Daniel et al. investigated the fire behavior of di-DOPO-isosorbide (DDI), diphenylphosphate isosorbide (DPPI), diphenylphosphinate isosorbide (DPPII) and isosorbide bis-(diethylphosphate) (IDEA) (Scheme 4) in epoxy resins containing $1 \mathrm{wt} \%$ phosphorus. The TGA results show an increased residue with increasing oxygen content in the chemical environment of the phosphorous atom in 
nitrogen atmosphere. The phosphate IDEA has the lowest onset temperature with $152{ }^{\circ} \mathrm{C}$. The thermal decomposition is initiated by the loss of the appropriate phosphorus acid, promoting highly crosslinked char due to Friedel-Crafts like reactions, dehydration and other reactions taking place in the degrading polymer.

\section{Biobased Flame Retardants in Polyesters}

\subsection{Poly (Lactic Acid)}

Due to its excellent properties PLA has reached commercial-scale production in recent years [151]. PLA features outstanding properties like biocompatibility, good mechanical properties, high transparency, low toxicity and flexible processability, thus it is suitable for a variety of applications [152-154]. Further utilization is limited by its poor fire performance, characterized especially by a high ignitability and flaming drips. Therefore flame retardants such as phosphorus-containing compounds, nitrogen-containing compounds and mineral fillers were incorporated and their flame retardant efficiency in PLA was investigated [155-157]. While there are already reviews covering the work of various research groups evaluating flame retardants in PLA, this review focuses solely on biobased flame retardants and their synergistic formulations [155-157].

Upon incorporation of only $5 \mathrm{wt}$ \% PCPP I (Scheme 1) PLA reaches a V-0 in the vertical UL94 burning test setup. Additionally, with increasing concentration of PCPP I (10 wt $\%)$ melt dripping was eliminated due to the formation of a cohesive char layer and the LOI value of PLA (21\%) was increased to $26 \%$ while the peak heat release rate (pHRR) was decreased by $16 \%$ in the cone calorimeter test [83].

SPDPM (Scheme 1) was melt blended with PLA in various concentrations in the range of 5-25 wt\%. The resulting PLA composites ( $5 \mathrm{wt} \%$, and $15 \mathrm{wt} \%)$ passed the UL94 test with a V-2 rating. At a concentration of $25 \mathrm{wt} \%$ SPDPM, a V-0 rating was obtained and the LOI value was increased to $38 \%$ while also reducing the dripping behavior. In microscale combustion calorimetry (MCC) experiments the $\mathrm{pHRR}$ value was decreased by $39 \%$ from $475 \mathrm{~W} / \mathrm{g}^{-1}$ to $291 \mathrm{~W} / \mathrm{g}^{-1}$ [84].

The addition of IFR-I and IFR-II (Scheme 1) in PLA improved the flame retardancy of PLA/IFR composites passing the vertical UL94 test. While an incorporation of $30 \mathrm{wt} \%$ IFR-II only reached a V-1 rating an increase of the concentration up to $20 \mathrm{wt} \%$ IFR-1 lead to a V-0 classification. Moreover, the PLA/IFR-I (20 wt \%) composite showed an LOI of 36\% and a decreased heat release capacity (HRC) of $33 \%$ in pyrolysis combustion flow calorimetry (PCFC) [85].

$4 \mathrm{wt} \%$ BPPT (Scheme 1) in PLA resulted in a V-0 rating in the vertical UL94 burning test and an increased LOI of 33\%. The PLA/BPPT blends show no significant difference to neat PLA in cone calorimeter test due to the lack of a char layer, which indicates a gas phase activity mainly responsible for the flame retardant effect [86]. In combination with polyethyleneimine-modified graphene oxide (M-GO), the proportion of flame retardant was further reduced to $3 \mathrm{wt} \%(2.4 \mathrm{wt} \% \mathrm{BPPT}, 0.6 \% \mathrm{M}-\mathrm{GO})$ while still passing the vertical UL94 test with a V-0 classification [158].

Upon addition of $5 \mathrm{wt} \% \mathrm{VP}$ (Scheme 2a) in PLA the corresponding composites obtained a V-0 classification and the LOI improved to $26 \%$. In the cone calorimeter test, the pHRR decreased by $10 \%$ and a less developed char layer along with a significant increase of evolved CO during the test indicate that gas phase action was the main flame retardant mechanism [88].

Melt blending of $7 \mathrm{wt} \%$ PCPP II (Scheme $2 \mathrm{~b}$ ) results in a V-0 rating with no melt dripping behavior in the UL94 test and an increased LOI value of $28 \%$ [89]. Further investigation of the thermal degradation behavior of the PLA/ PCPP II system using TGA, TGA-FTIR and Py-GC-MS revealed an improved thermal stability after $10 \%$ decomposition of the blend took place and confirmed the gas-phase action of PCPP II [159].

Upon incorporation of $5 \mathrm{wt} \%$ of PPLA I (Scheme 2c) PLA reached a UL94 V-0 rating and a LOI value of $34 \%$. The pHRR was decreased by $23 \%$ from $436 \mathrm{~kW} / \mathrm{m}^{-2}$ to $337 \mathrm{~kW} \mathrm{~m}^{-2}$ [90]. PPLA II (Scheme 2d) achieved a V-0 rating when $10 \mathrm{wt} \%$ were added in PLA. A LOI value of $28 \%$ and a decreased pHRR by $19 \%$ was obtained [91]. 
Isosorbide-based polyphosphonate (PPPI, Scheme 3) was added to PLA via melt blending and the corresponding composites were characterized by vertical UL94 test setup and cone calorimeter test. Even though the addition of $15 \mathrm{wt} \%$ PPPI did not significantly reduce the pHRR a V-0 classification was obtained [34].

Besides the incorporation of novel synthesized biobased flame retardants, various research groups used another approach to produce flame retardant PLA by using biomass derived charring agents with little or no chemical modification in flame retardant systems. A prominent example used in intumescent flame retardant formulations is lignin. Réti et al. evaluated the flame retardant efficiency of lignin $(10 w t \%)$ in combination with APP (30 wt \%) and compared it to APP/PER (10/30 wt $\%)$ and APP/starch (10/30 wt\%) formulations [160]. Although the highest LOI values were obtained with the PLA/APP/PER composite (60\%) followed by the PLA/APP/starch (40\%) and the PLA/APP/lignin (32\%) composite, only the materials containing lignin or starch reach a V-0 classification in UL94 test. In the cone calorimeter test all formulations have a decreased pHRR of at least $40 \%$ up to $60 \%$ due to the formation of intumescent protective layers with the APP/PER formulation being the most efficient one.

Zhang et al. compared the flame retardant effect of virgin lignin and urea modified lignin (UM-lignin) in combination with APP in PLA [99]. While the formulations containing APP/lignin (18.4 wt\%/4.6 wt\%) and APP/UM-lignin both showed similar LOI values (33-34\%) only the UM-lignin containing composite obtained a V-0 rating in the UL94 test. A reduction of the peak heat release rate by $64-75 \%$ was achieved for both composites with the UM-lignin formulation having the better performance in terms of cone calorimeter tests. Scanning electron microscopy (SEM) and X-ray photoelectron spectroscopy (XPS) confirm denser char morphology with more phosphorus-containing char for the APP/UM-lignin system.

Costes et al. carried out a simple phosphorus/ nitrogen modification on two different lignins (kraft and organosolv) and evaluated their flame retardant effect in PLA [161]. Upon incorporation of $20 \mathrm{wt} \%$ of lignin the pHRR decreases by $30 \%$ but only the chemically modified lignin reached a V-0 rating in the UL94 test. Nevertheless, gel permeation chromatography (GPC) results confirmed thermal degradation of PLA when adding lignin, no matter if modified or not. In order to limit the decrease in molecular weight induced by the addition of lignin, Costes et al. combined lignin with phytic acid [162]. The presence of the acid enabled better dispersion of lignin into the PLA matrix and reduced the thermal degradation caused by it. Likewise, lignin reduced the composite hygroscopy induced by the presence of phytic acid. Moreover, incorporation of the phytic acid-lignin combination leads to an improved fire behavior. With the addition of $10 \mathrm{wt} \%$ lignin and 10\% phytate in PLA a reduction of the pHRR by $44 \%$ was achieved while obtaining a V-2 classification in the vertical UL94 test.

The incorporation of several metallic phytates (Na-, Al-, Fe-, La-Phyt) with different oxidation states of the metal centers in PLA was studied by Costes et al. as well [163]. Aluminum phytate was proven to be the best compound compared to the other salts regarding their flame retardant properties but also being the most efficient initiator for PLA degradation during melt processing. To limit reduction of the molecular weight Al-Phyt was combined with Na-Phyt, which triggered a reduced degradation during melt blending in PLA. The Na-/ Al-Phyt (15 wt\%/5 wt\%) combination reduced the $\mathrm{pHHR}$ by $45 \%$ and obtained a V-2 rating in the UL94 test. Inductively coupled plasma (ICP) analysis of the char formed during the combustion showed that the used metallic phytate salts act in the condensed phase.

The addition of a novel phytate salt based on tannic acid and polyethyleneimine (Phyt/PEI-TA) in PLA was investigated by Laoutid et al. [164]. Upon incorporation of $20 \mathrm{wt} \%$ (Phyt/PEI-TA) the pHRR was decreased by 37\%. Due to IPC analysis, it was found that the phosphorus remained mainly in the condensed phase confirming the condensed phase action of Phyt/PEI-TA.

The flame retardant effect of Al-Phyt in PLA was evaluated in combination with phosphorylated cellulose (P-cellulose) [165]. The Al-Phyt/ P-cellulose (5 wt\%/10 wt $\%$ ) composite allowed a reduction of the pHRR by $38 \%$ and reached a V-2 classification in the UL94 test due to the formation of a stable insulating char layer. 
Fox et al. used polyhedral oligomeric silsesquioxane (POSS)-modified nanofibrillated cellulose (PNFC) as a carbon source in intumescing flame retardant formulations in PLA [166,167]. The bulky POSS groups inhibited the general problem of degradation of PLA when using APP due to a reduced phosphate accessibility to the polymer backbone. In the cone calorimeter test the PLA/APP/PNFC (11.25 $\mathrm{wt} \% / 3.75 \mathrm{wt} \%$ ) composite showed a reduced pHRR by $46 \%$, being slightly better than the comparable composite containing APP/PER (11.25 wt \%/3.75 wt \%). Both composites obtained a V-0 rating in the UL94 burning test.

Vahabi et al. investigated the application of a biobased flame retardant containing hydroxyapatite, perylene and lignocellulose (LHP) in PLA. When incorporated in combination with APP at a 1:3 ratio (LHP: APP) the pHRR was decreased by $32 \%$ in the cone calorimeter test due to an enhanced char formation [168].

Chen et al. evaluated the effect of chitosan (CS) on the flammability of PLA/APP composites [169]. PLA containing a combination of $5 \mathrm{wt} \%$ APP with $2 \mathrm{wt} \%$ CS led to an LOI of $33 \%$, passed the UL94 V-0 rating and decreased the pHRR by $17 \%$. Fourier transform infrared spectroscopy (FTIR) and TGA results indicate that CS acts as carbon agent due to its high content of carbon while characterization of the char residue by SEM confirmed the formation of a dense, homogeneous and continuous char layer.

Feng et al. investigated the addition of $\beta$-cyclodextrin (CD) as a carbon source in an intumescent flame retardant system consisting of APP and melamine (MA) [170]. When introduced in PLA, the corresponding composites had an increased LOI value of $34 \%$ and reached a V-0 classification in the UL94 test. Wang et al. prepared an inclusion complex between CD and poly(propylene) glycol (PPG) and added it in combination with APP and MA into PLA via melt blending [171]. This system exhibited more effective carbonization compared to the composite containing free $\mathrm{CD}$. A LOI value of $34 \%$ and $\mathrm{V}-0$ rating were obtained while the pHRR was decreased by $73 \%$.

Wang et al. prepared PLA/APP/starch composites and evaluated the flame retardant properties by LOI, UL94 test and MCC [172]. Upon incorporation of $20 \mathrm{wt} \%$ APP and $10 \mathrm{wt} \%$ starch a LOI value of $41 \%$ and a reduction of the pHRR by $76 \%$ was reached. Moreover, a V-0 rating without any melt dripping behavior was obtained in the UL94 test.

Zhang et al. incorporated casein, a phosphoprotein derived from milk with a high phosphorus and nitrogen content, into PLA via melt compounding [173]. The results showed that the introduction of $20 \mathrm{wt} \%$ casein led to composites with an increased LOI value of $32 \%$ and a decreased pHRR by $18 \%$. In the UL94 test a V-0 rating was achieved. Mechanism analysis by FTIR and SEM indicated that casein took effect in both the gas phase by releasing nonflammable gases and the condensed phase by the formation of a char layer.

\subsection{Poly (Ethylene Therephthalate)}

Poly(ethylene terephthalate) as engineering plastic is used in many applications like packaging or construction materials due to its lightweight properties and stability. Triphenylphosphate (TPP) has toxicological effects but it can be incorporated in the cavities of $\beta$-cyclodextrin (CD) forming an inclusion complex (IC) to decrease these effects while the flame retardant efficacy is maintained in hot pressed PET films. Different formulations were made containing CD, TPP or the inclusion complex in PET. The film thickness was about $0.3 \mathrm{~mm}$ and flame retardancy tests showed that PET containing only CD burned completely while PET containing IC or TPP had self-extinguish properties with shorter burining times for the PET-IC film [174].

In a layer-by-layer process PET foams are coated with DNA (Scheme 6) and compared with a coating containing APP. The flame retardant coating consisting of DNA was homogeneously allocated on the surface and able to reduce the heat release rate peak by $7 \%$ whereas the performance of APP reduced the heat release rate peak by $25 \%$ when 4 quad-layers are applied on the foams. The coating containing DNA was not able to prevent the melt dripping in contrast to the APP containing coating. Both flame retardants had no significant effect on the time to ignition [105]. Alongi et al. applied a homogenous DNA coating on bulk PET (thickness $3 \mathrm{~mm}$ ) by a hot compression molding process at 
$120{ }^{\circ} \mathrm{C}$ resulting in a total amount of $10 \mathrm{wt} \%$ DNA in the polymer sample. A reduction of peak heat release rate by $42 \%$ could be achieved under $35 \mathrm{~kW} / \mathrm{m}^{-2}$ [107].

Cotton fabrics were treated with an aqueous DNA solution by an impregnation process by Alongi et al. and showed no ignition during cone calorimetry tests with an irradiative heat flux of $35 \mathrm{~kW} / \mathrm{m}^{-2}$ and an increase of LOI by $10 \%$ compared to untreated cotton fabrics [111]. Further investigations showed that a concentration of $19 \mathrm{wt} \%$ DNA leads to a fire resistance when the cotton fabrics are treated with an irradiation of $35 \mathrm{~kW} / \mathrm{m}^{2}$ in the cone calorimeter leading to a pyrolysis instead of burning [110].

Alongi et al. demonstrated that DNA is suitable as a coating for EVA, PP, PET, PA6 and ABS bulk samples. The fire behavior was evaluated by using cone calorimetry with an irradiation of 35 and $50 \mathrm{~kW} / \mathrm{m}^{-2} .10 \mathrm{wt} \%$ DNA content in the whole sample has emerged as an optimum concentration for $3 \mathrm{~mm}$ thick samples. For all samples the time to ignition was increased and the peak heat release rate was decreased significantly for an irradiation of 35 and $50 \mathrm{~kW} / \mathrm{m}^{-2}$. Under $35 \mathrm{~kW} / \mathrm{m}^{-2}$ the time to ignition could be increased by $342 \%$ (PET + $10 \mathrm{wt} \%$ DNA) up to $1637 \%$ (PA6 + $10 \mathrm{wt} \%$ DNA) and the peak heat release rate by $42 \%$ (PET + $10 \mathrm{wt} \%$ DNA) down to 57\% (ABS + $10 \mathrm{wt} \%$ DNA) [107]. A layer-by-layer coating of DNA for PET foams was compared to a corresponding coating containing APP (ammonium polyphosphate) by Alongi et al. [105].

The fire and the anti-dripping behavior of PET fabrics could be improved by a deposition of chitosan and ammonium polyphosphate on the PET fabrics by using a layer-by-layer assembly technique. A 20 bilayer assembly on PET fabrics result in an increase of the LOI by $24 \%$ and no melt dripping during the vertical burning test [175].

A casein treated PET fabric results in an increased residue of $9 \%$ after a heat flux of $35 \mathrm{~kW} \mathrm{~m}^{-2}$ and a reduction in peak heat release rate of $2.7 \%$ but cannot prevent the melt dripping behavior. The time to ignition is decreased by $112 \mathrm{~s}$ for neat PET fabric to $62 \mathrm{~s}$ for casein treated PET fabrics. The horizontal flame spread test revealed a reduction of the burning rate by $67 \%$ and an increased residue of $34 \%$ [112,113].

Phosphorous-containing PER compounds were also tested for PET and PBT [104,176] DOPO-PEPA (Scheme 7) was used in PET fibers with a total phosphorus content of $0.8 \mathrm{wt} \%$ reaching a UL94 V-0 classification [176]. $5 \mathrm{wt} \%$ DOPO-PEA in PET resulted in a LOI value of 35.2\% (neat PET: 24.6\%) with no melt dripping behavior. The same amount of DOPO-PEPA in PBT led to a less intense melt dripping behavior an increase of the LOI value from $24.4 \%$ to $28.5 \%$ [104].

DOPO-IA (Scheme 5) can be synthesized via Michael addition type reaction of DOPO and itaconic acid and was developed by Toyo Boeski in 1975 [177]. A low molecular weight polymer consisting of DOPO itaconate and ethylene glycol was used for PBT, PA, TPE and PET [178]. Due to the acid groups of DOPO-IA it can be esterified resulting in different phosphorus-containing polyesters [101] or incorporated in the PET backbone via reactive extrusion (PET-P) [179]. PET-P has a total phosphorus content of $0.6 \mathrm{wt} \%$ and leads to an increase in the pyrolysis char yield in nitrogen atmosphere of $21 \%$ in comparison to neat PET with $17.9 \%$ [179].

$25 \mathrm{wt} \%$ of GL-3DOPO (2.69\% phosphorus content, Scheme 6) in PET resulted in 17.3\% char residue at $750{ }^{\circ} \mathrm{C}$ compared to $7.9 \%$ for neat PET in nitrogen atmosphere. $25 \mathrm{wt} \%$ of GL-3DOPO in PET is suitable for a V-0 classification in the UL94 vertical burning test without burning drips. MCC tests showed a decrease of the multipeak heat release capacity (MHRC) of $481 \mathrm{Jg}^{-1} / \mathrm{K}^{-1}$ in comparison to neat PET with $568 \mathrm{Jg}^{-1} / \mathrm{K}^{-1}$. The LOI was increased from 22.8 to $35.4 \%$ (25 wt $\%$ GL-3DOPO in PET) for PET and also increased from 20.2 to $27.9 \%$ (25 wt \% GL-3DOPO in PBT) for PBT. A total phosphorus content of $0.5 \%$ can achieve a V-2 classification in UL94 vertical burning tests whereas total phosphorus contents from $0.8 \%$ to $2.5 \%$ result in a V-0 classification for GL-3DOPO in PET. For PBT a total phosphorus content of $1.5 \%$ was able to achieve a V-0 classification and from $2.0 \%$ up to $2.5 \%$ a V-0 classification was obtained [103]. 


\subsection{Poly (Butylene Succinate)}

Polybutylene succinate (PBS) can be obtained by polycondensation of 1,4-butandiol and succinic acid, resulting in a biodegradable polymer. It is used for medical articles [180], food packaging [181], cosmetic bottles [182], etc. Hu et al. investigated flame retardants containing isosorbide modified with sulfur, phosphorus and silicon chlorides resulting in molecular or polymer flame retardants for polybutylene succinate. The phosphorus containing flame retardants are composed of phosphonates (DDI), phosphates (PPPAI, DPPI, PPPI) and phosphinates (DPPII) (Scheme 4) and were tested in PBS at a loading of $15 \%$. Isosorbide modified with phosphorus showed better performance in terms of fire behavior than the flame retardants modified with silicon or sulfur. Regarding UL94 $15 \mathrm{wt} \%$ of the phosphorus flame retardants respectively reached V-0 classification with non-burning dripping. $15 \mathrm{wt} \%$ of the phosphinate (DPPII) and the phosphonate (DDI) flame retardant in PBS in each case lead to an increased time to ignition of $38 \mathrm{~s}$ (DPPI) and $95 \mathrm{~s}$ (DDI). The phosphate flame retardants (PPPI, PPPAI, DPPII) promote the formation of char but the peak heat release rates are significantly increased up to $107 \%$ [97].

Ferry et al. grafted phosphoros compounds onto lignin for PBS and compared it with unmodified lignin whose flame retardant properties are known in the literature [51,52]. Ferry et al. compared the two neat lignins also by using cone calorimetry and reported different pHRR and TTI (time to ignition) for the alkali $\left(102 \mathrm{~kW} / \mathrm{m}^{-2}\right.$ and $\left.189 \mathrm{~s}\right)$ and organosolv $\left(111 \mathrm{~kW} / \mathrm{m}^{-2}\right.$ and $\left.25 \mathrm{~s}\right)$ lignin. Unmodified lignin in PBS leads to a decreased time to ignition and heat release rate with charring behavior. In comparison, lignin modified with phosphorus-containing homo- and copolymers in PBS was able to improve the fire behavior due to the formation of a more stable char. In cone calorimetry tests the THR was slightly decreased from $22.1 \mathrm{~kJ} / \mathrm{g}^{-1}$ (neat PBS) down to $19.0 \mathrm{~kJ} / \mathrm{g}^{-1}$ (PBS + 20\% Lig Alk) and the pHRR was halfed. Phosphorus-modified lignin was able to increase the $\mathrm{pHRR}$ reduction from $562 \mathrm{~kW} / \mathrm{m}^{-2}$ (neat PBS) down to $270 \mathrm{~kW} / \mathrm{m}^{-2}$ (PBS + 20\% Lig AlkcopoP) [53].

\section{Biobased Flame Retardants in Epoxy Resins}

The different epoxy monomers shown in Section 2.3.1 were designed for different applications. Therefore, the different resins cannot be compared to each other, but to a reference system. Ménard et al. [62] incorporated P2EP1P to the systems DGEBA/IPDA, P3EP/IPDA, P3EP/DA10, P3EP/DIFFA (IPDA = isophorone diamine, P3EP = triglycidyl phloroglucinol, DA10 = decane-1,10-diamine, DIFFA $=$ difurfurylamine) yielding $1 \%$ or $3 \%$ phosphorus content in the matrix. Systems containing P2EP1P lead to lower pHRR and THR in pyrolysis combustion flow calorimetry (PCFC) because of a higher char yield (detected in TGA at $700^{\circ} \mathrm{C}$ ) and EHC (effective heat of combustion). It was shown, that the residue at $700{ }^{\circ} \mathrm{C}$ is over $30 \%$ for $3 \% \mathrm{P}$ in DGEBA/IPDA and only $9 \%$ without the incorporated flame retardant. The pHRR is analogically lowered by $50 \%$. This effect is also observable for systems with lower P-loadings, but less distinctive. On the other hand, the glass transition temperature of the matrix is lowered by the incorporation of P2EP1P significantly up to $50^{\circ} \mathrm{C}$.

Ma et al. [45] investigated the system consisting of DGEBA/EADI/MHHPA (MHHPA = methyl hexahydrophthalic anhydride) in different compositions between 100/0/68 and 52/48/62 as well as a system without DGEBA 0/100/56. This leads to phosphorus contents between $0 \%$ and $4.4 \%$. The sample containing $4.4 \%$ phosphorus without DGEBA achieves a V-0 rating in UL94 vertical flammability tests. The glass transition temperature of this sample is $102^{\circ} \mathrm{C}$ and therefore $8{ }^{\circ} \mathrm{C}$ lower than the glass transition temperature of the sample without EADI. Ma et al. deduce this observation from a lower crosslinking density because of steric hindrance in EADI and MHHPA. The change in flexural strength is within the error range for the different samples.

Neat DOPO-III or a combination with 10-undecenoyl triglyceride (UDTGE) or 3,4,5-tris (10-undecenoyloxy) benzoate (UDBME) was cured with 4,4'-diaminodiphenylmethane (DDM) or bis( $m$-aminophenyl) methylphosphine oxide (BAMPO) by Lligadas et al. [60]. Resulting thermoset materials show increased LOI values for phosphorus containing samples and glass transition temperatures at $108^{\circ} \mathrm{C}$ with DDM and $95^{\circ} \mathrm{C}$ with BAMPO. 
Eugenol and cardanol based flame retardant epoxy monomers were tested after curing with MXDA (meta-xylenediamine) by Calliol et al. [41] with DGEBA as reference epoxy resin. The phosphorus content in the matrix depends on the monomer structure and varies between $2 \%$ and $6 \%$. The glass transition temperatures for eugenol based resins are about $100{ }^{\circ} \mathrm{C}$ lower than for the DGEBA-based system. PCFC tests show that the $\mathrm{pHRR}$ is lowered by $25 \%$ for phosphorus containing samples, whereas the residue is increased by up to $55 \%$. These results are similar to results obtained by Miao et al. [183] curing TEEP with DDM.

Flame retardant curing agents were tested by partially replacing non-biobased curing agents in epoxy resin systems. Dai et al. [135] cured DGEBA with DDM and DOPO-PHM. A 50/50 mixture of these curing agents and a resulting phosphorus content of $1.7 \%$ in the matrix leads to an increase in LOI up to $33 \%$. The char yield at $700{ }^{\circ} \mathrm{C}$ under nitrogen atmosphere is increased by $6 \%$. A single glass transition temperature around $100^{\circ} \mathrm{C}$ indicates a homogenous material.

The bisphenolic structure Ar-DOPO-N synthesized by Liu et al. [36] was tested in reference to $o$-cresol formaldehyde novolac epoxy resin (CNE) cured with phenol formaldehyde novolac (PFN) and melamine-modified novolac (MPFN) in different ratios. The resulting glass transition temperature is decreased by $20^{\circ} \mathrm{C}$ for samples with $30 \mathrm{wt} \%$ flame retardant curing agent in the matrix. The LOI is simultaneously raised from $21 \%$ to $33 \%$. The residue at $700{ }^{\circ} \mathrm{C}$ is increased from $30 \%$ for the sample without phosphorus to over $50 \%$ for the sample with $30 \mathrm{wt} \%$ AR-DOPO-N incorporated. A P-N synergistic effect was shown for the melamine-containing system.

Hydroxyl PES was designed as a flame retardant curing agent for epoxy films by Lin et al. [136] and tested in DGEBA, CNE and HP-7200. Resulting systems are transparent, tough, achieve V-0 in UL94 vertical tests setups and have a high glass transition temperature of about $260^{\circ} \mathrm{C}$. An application for LED encapsulation is suggested.

The myrcene-based MMDOPO prepared by Yang et al. [57] was cured with DGEBA and DMP as accelerator. While the resulting material showed an increased LOI and a moderate glass transition temperature of $100{ }^{\circ} \mathrm{C}$, it was brittle at the same time. Hence, it was combined with a phosphate containing castor oil derived curing agent combining balanced strength and elongation at break.

Polyesters by Wang et al. [69] were cured with epoxidized soybean oil. Only samples with a higher phosphorus content than $2 \%$ achieved a V-2 classification in UL94 tests. Flame retardant efficiency was shown by microcombustion calorimetry (MCC). The peak heat release rate was decreased by $50 \%$ and the total heat release was decreased by $7 \%$. For a possible application in PSA tapes, the samples were tested additionally after procedure GB/T 15903-1995 [184], achieving an enhanced result (level 1) because of an observed self-extinguishment. Reference samples consisting of polyesters without incorporated phosphorus groups burned completely.

TECP containing DOPO-groups were incorporated to DGEBA/DDM by Hu et al. [18]. A flame retardant content of $30 \mathrm{wt} \%$ in the matrix shows an increased LOI by about $30 \%$. The char residue at $800{ }^{\circ} \mathrm{C}$ in nitrogen atmosphere is $8 \%$ and the pHRR was decreased by $50 \%$ in cone calorimeter measurements compared to DGEBA/DDM samples. Mechanical tests showed increased impact strength.

The nano-filler obtained from phytic acid was dispersed in DGEBA/m-DPA (meta-phenylenediamine) and achieves a V-0 classification in UL94 tests and a LOI of about $30 \%$ for samples with $20 \mathrm{wt} \%$ or $30 \mathrm{wt} \%$ PAMA incorporated to the matrix. The pHRR was decreased by $45 \%$ in reference to a system cured with $N$-aminoethylpiperazine, while the residue after cone calorimeter tests is increased from $3 \%$ to $35 \%$.

The determined inclusion complex showed a delay in decomposition referring to the flame retardant molecule without the inclusion complex. Zhao et al. [145] detected an increased residue at $600{ }^{\circ} \mathrm{C}$ and a decreased pHRR by $36 \%$ for $2 \mathrm{wt} \%$ incorporated inclusion complex. They propose a flame retardant mode of action in the gas and condensed phase.

PER based flame retardant PFR was tested in DGEBA/DDM [138]. At $15 \mathrm{wt} \%$ PFR content the system achieved V-0 in vertical UL94 test and the PHRR was lowered by $60 \%$ in MCC. The glass 
transition temperature is higher for samples containing PFR. Because of the high loading tensile strength is lowered to $17 \mathrm{MPa}$, whereas elongation at break was higher by $50-70 \%$.

DOPO-PEPA was tested by Zhang et al. [106] in DGEBA/DDM. At 5.7wt\% DOPO-PEPA content the system achieves a V-0 classification and a LOI of about $30 \%$. Also the pHRR was decreased by $32 \%$ to $873 \mathrm{~kW} / \mathrm{m}^{-2}$. A reference system with $9.1 \mathrm{wt} \%$ DOPO achieved similar results in cone calorimeter and LOI tests. But it achieved no rating in UL94 testing.

\section{Outlook}

Within a few years, many biobased flame retardant systems were developed, but an industrial scale up will not be feasible so fast. A successful flame retardant is determined by the flame retardant efficiency or potential flame retardant formulations. We showed that there are many different systems available, which can be improved through ongoing research. Promising flame retardant structures for epoxy resins are realized with biobased epoxides or curing agents. Such compounds from petrochemical sources are bio-accumulative and have negative effects on health of human and environment. On the other hand, biobased molecules are not per se healthy. Chemically modified they are equal to their petrochemical equivalents und thus have the same health safety issues. Therefore, toxicology of all substances still must be determined. As we can see from BPA, some structures are available from renewable sources, but from an economical point of view, they are not profitable, because the petrochemical alternative is less expensive to produce. In terms of rising crude oil prices, the research on alternative production chains is important for the future. Some production chains, which are too expensive nowadays, will be viable in future. The cost of an industrial scale up depends on required technologies and raw materials. Some of the presented materials are based on special organisms and others on byproducts of industrial processes like wine or wood production. These byproducts which are available in large scales are more prone to be considered raw materials for new biobased flame retardant systems.

The increasing market and interest in biobased polymers and biobased additives like flame retardants is a positive trend but during the replacement process recycling and the whole production process of biobased polymers including the extraction of raw materials are essential aspects that have to be considered in the evaluation of the life cycle assessment (LCA). The recycling process of plastics which contain additives like flame retardants (biobased or non-biobased) is more difficult than the recycling of neat polymers, because the effects of the additives can be reduced or the polymer characteristics can be influenced throughout the recycling loop. Research in this area is still needed and an important challenge in the future. The limited access to fossil-based resources encourages the growth of the biobased polymers and biobased platform chemicals due to identical properties of end products. There is a change in the plastic industry because the biodegradable plastics are no longer attractive for niche applications. Certain production processes for raw materials and chemicals made of renewable sources require water and land use which are no longer available for food production generating a competition of land use.

Author Contributions: All authors contributed equally to this work.

Conflicts of Interest: The authors declare no conflict of interest.

\section{References}

1. Vert, M.; Doi, Y.; Hellwich, K.-H.; Hess, M.; Hodge, P.; Kubisa, P.; Rinaudo, M.; Schué, F. Terminology for biorelated polymers and applications (IUPAC Recommendations 2012). Pure Appl. Chem. 2012, 84, 377-410. [CrossRef]

2. ASTM International. Standard Test Methods for Determining the Biobased Content of Solid, Liquid, and Gaseous Samples Using Radiocarbon Analysis; ASTM International: West Conshohocken, PA, USA, 2011.

3. Verma, D.; Fortunati, E. Biopolymer Processing and its Composites: An Introduction. In Biomass, Biopolymer-Based Materials, and Bioenergy; Woodhead Publishing: Sawston, Cambridge, UK, 2019; pp. 3-23. 
4. Rudin, A.; Choi, P. The Elements of Polymer Science and Engineering; Academic Press: Cambridge, MA, USA, 2012; ISBN 0123821797.

5. Emblem, A. Plastics properties for packaging materials. Packag. Technol. 2012, 13, 287-309. [CrossRef]

6. Mishnaevsky, L.; Branner, K.; Petersen, H.N.; Beauson, J.; McGugan, M.; Sørensen, B.F. Materials for Wind Turbine Blades: An Overview. Materials 2017, 10, 1285. [CrossRef] [PubMed]

7. Fathi, A.; Keller, J.H.; Altstaedt, V. Full-field shear analyses of sandwich core materials using Digital Image Correlation (DIC). Compos. Part B Eng. 2015, 70, 156-166. [CrossRef]

8. Müller, R.-J.; Schrader, H.; Profe, J.; Dresler, K.; Deckwer, W.-D. Enzymatic Degradation of Poly(ethylene terephthalate): Rapid Hydrolyse using a Hydrolase fromT. fusca. Macromol. Rapid Commun. 2005, 26, 1400-1405. [CrossRef]

9. Endres, H.J.; Siebert-Raths, A.; Behnsen, H.; Schulz, C. Biopolymers Facts and Statistics; IfBB - Institut für Biokunststoffe und Bioverbundwerkstoffe: Hannover, Germany, 2016; pp. 2363-8559.

10. Robertson, G.L.; Sand, C.K. Bio-Derived Polymers for Food Packaging; Institute of Food Technologists: Chicago, IL, USA, 2018.

11. Kriegel, R.M.; Huang, X.; Schultheis, M.W. Bio-Based Polyethylene Terephthalate Polymer and Method of Making Same. US2009246430A1, 1 October 2009.

12. Harmsen, P.F.H.; Hackmann, M.M.; Bos, H.L. Green building blocks for bio-based plastics. Biofuels Bioprod. Biorefining 2014, 8, 306-324. [CrossRef]

13. Pellis, A.; Acero, E.H.; Ferrario, V.; Ribitsch, D.; Guebitz, G.M.; Gardossi, L. The Closure of the Cycle: Enzymatic Synthesis and Functionalization of Bio-Based Polyesters. Trends Biotechnol. 2016, 34, 316-328. [CrossRef]

14. Cayla, A.; Rault, F.; Giraud, S.; Salaün, F.; Fierro, V.; Celzard, A. PLA with Intumescent System Containing Lignin and Ammonium Polyphosphate for Flame Retardant Textile. Polymers 2016, 8, 331. [CrossRef]

15. Jensen, J.; Skelton, K. Wind turbine blade recycling: Experiences, challenges and possibilities in a circular economy. Renew. Sustain. Energy Rev. 2018, 97, 165-176. [CrossRef]

16. Alongi, J.; Carosio, F.; Kiekens, P. Recent Advances in the Design of Water Based-Flame Retardant Coatings for Polyester and Polyester-Cotton Blends. Polymers 2016, 8, 357. [CrossRef]

17. Chen, L.; Pelton, R.E.; Smith, T.M. Comparative life cycle assessment of fossil and bio-based polyethylene terephthalate (PET) bottles. J. Clean. Prod. 2016, 137, 667-676. [CrossRef]

18. Wang, X.; Zhou, S.; Guo, W.W.; Wang, P.L.; Xing, W.; Song, L.; Hu, Y. Renewable Cardanol-Based Phosphate as a Flame Retardant Toughening Agent for Epoxy Resins. ACS Sustain. Chem. Eng. 2017, 5, 3409-3416. [CrossRef]

19. Schartel, B.; Balabanovich, A.I.; Braun, U.; Knoll, U.; Artner, J.; Ciesielski, M.; Doring, M.; Pérez, R.; Sandler, J.K.W.; Altstädt, V.; et al. Pyrolysis of epoxy resins and fire behavior of epoxy resin composites flame-retarded with 9,10-dihydro-9-oxa-10-phosphaphenanthrene-10-oxide additives. J. Appl. Polym. Sci. 2007, 104, 2260-2269. [CrossRef]

20. Wang, X.; Kalali, E.N.; Wang, D.-Y. Renewable Cardanol-Based Surfactant Modified Layered Double Hydroxide as a Flame Retardant for Epoxy Resin. ACS Sustain. Chem. Eng. 2015, 3, 3281-3290. [CrossRef]

21. Greiner, L.; Kukla, P.; Eibl, S.; Döring, M. Phosphorus Containing Polyacrylamides as Flame Retardants for Epoxy-Based Composites in Aviation. Polymers 2019, 11, 284. [CrossRef]

22. Jin, F.L.; Li, X.; Park, S.J. Synthesis and application of epoxy resins: A review. J. Ind. Eng. Chem. 2015, 29, 1-11. [CrossRef]

23. Bell, B.M.; Briggs, J.R.; Campbell, R.M.; Chambers, S.M.; Gaarenstroom, P.D.; Hippler, J.G.; Hook, B.D.; Kearns, K.; Kenney, J.M.; Kruper, W.J.; et al. Glycerin as a Renewable Feedstock for Epichlorohydrin Production. The GTE Process. Clean Soil Air Water 2008, 36, 657-661. [CrossRef]

24. Rad, E.R.; Vahabi, H.; de Anda, A.R.; Saeb, M.R.; Thomas, S. Bio-epoxy resins with inherent flame retardancy. Prog. Org. Coat. 2019, 135, 608-612. [CrossRef]

25. Perez, R.M.; Sandler, J.K.W.; Altstädt, V.; Hoffmann, T.; Pospiech, D.; Ciesielski, M.; Doring, M. Effect of DOP-based compounds on fire retardancy, thermal stability, and mechanical properties of DGEBA cured with 4, 4'-DDS. J. Mater. Sci. 2006, 41, 341-353. [CrossRef]

26. Qian, L.-J.; Ye, L.-J.; Xu, G.-Z.; Liu, J.; Guo, J.-Q. The non-halogen flame retardant epoxy resin based on a novel compound with phosphaphenanthrene and cyclotriphosphazene double functional groups. Polym. Degrad. Stab. 2011, 96, 1118-1124. [CrossRef] 
27. Gao, L.-P.; Wang, D.-Y.; Wang, Y.-Z.; Wang, J.-S.; Yang, B. A flame-retardant epoxy resin based on a reactive phosphorus-containing monomer of DODPP and its thermal and flame-retardant properties. Polym. Degrad. Stab. 2008, 93, 1308-1315. [CrossRef]

28. Guo, J.; Song, H.; Liu, H.; Luo, C.; Ren, Y.; Ding, T.; Khan, M.A.; Young, D.P.; Liu, X.; Zhang, X.; et al. Polypyrrole-interface-functionalized nano-magnetite epoxy nanocomposites as electromagnetic wave absorbers with enhanced flame retardancy. J. Mater. Chem. C 2017, 5, 5334-5344. [CrossRef]

29. Hussain, M.; Varley, R.J.; Mathys, Z.; Cheng, Y.B.; Simon, G.P. Effect of organo-phosphorus and nano-clay materials on the thermal and fire performance of epoxy resins. J. Appl. Polym. Sci. 2004, 91, 1233-1253. [CrossRef]

30. Zhang, X.; He, Q.; Gu, H.; Colorado, H.A.; Wei, S.; Guo, Z. Flame-Retardant Electrical Conductive Nanopolymers Based on Bisphenol F Epoxy Resin Reinforced with Nano Polyanilines. ACS Appl. Mater. Interfaces 2013, 5, 898-910. [CrossRef] [PubMed]

31. Kalali, E.N.; Wang, X. Functionalized layered double hydroxide-based epoxy nanocomposites with improved flame retardancy and mechanical properties. J. Mater. Chem. A 2015, 3, 6819-6826. [CrossRef]

32. Polen, T.; Spelberg, M.; Bott, M. Toward biotechnological production of adipic acid and precursors from biorenewables. J. Biotechnol. 2013, 167, 75-84. [CrossRef]

33. Raj, K.; Partow, S.; Correia, K.; Khusnutdinova, A.N.; Yakunin, A.F.; Mahadevan, R. Biocatalytic production of adipic acid from glucose using engineered Saccharomyces cerevisiae. Metab. Eng. Commun. 2018, 6, $28-32$. [CrossRef]

34. Adom, F.; Dunn, J.B.; Han, J.; Sather, N. Life-Cycle Fossil Energy Consumption and Greenhouse Gas Emissions of Bioderived Chemicals and Their Conventional Counterparts. Environ. Sci. Technol. 2014, 48, 14624-14631. [CrossRef]

35. Yim, H.; Haselbeck, R.; Niu, W.; Pujol-Baxley, C.; Burgard, A.; Boldt, J.; Khandurina, J.; Trawick, J.D.; Osterhout, R.E.; Stephen, R.; et al. Metabolic engineering of Escherichia coli for direct production of 1,4-butanediol. Nat. Methods 2011, 7, 445-452. [CrossRef]

36. Liu, Y.L.; Wu, C.S.; Hsu, K.Y.; Chang, T.C. Flame-retardant epoxy resins fromo-cresol novolac epoxy cured with a phosphorus-containing aralkyl novolac. J. Polym. Sci. Part A Polym. Chem. 2002, 40, 2329-2339. [CrossRef]

37. Buck, K.T.; Boeing, A.J.; Dolfini, J.E. Method of Producing Benzaldehyde. U.S. Patent US4673766, 16 June 1987.

38. Van Haveren, J.; Scott, E.L.; Sanders, J. Bulk chemicals from biomass. Biofuels Bioprod. Biorefining 2008, 2, 41-57. [CrossRef]

39. Barreto, A.; Esmeraldo, M.; Rosa, D.; Fechine, P.; Mazzetto, S. Cardanol biocomposites reinforced with jute fiber: Microstructure, biodegradability, and mechanical properties. Polym. Compos. 2010, 31, 1928-1937. [CrossRef]

40. Miao, J.T.; Yuan, L.; Guan, Q.; Liang, G.; Gu, A. Biobased Heat Resistant Epoxy Resin with Extremely High Biomass Content from 2,5-Furandicarboxylic Acid and Eugenol. ACS Sustain. Chem. Eng. 2017, 5, 7003-7011. [CrossRef]

41. Ecochard, Y.; DeCostanzi, M.; Negrell, C.; Sonnier, R.; Caillol, S. Cardanol and Eugenol Based Flame Retardant Epoxy Monomers for Thermostable Networks. Molecules 2019, 24, 1818. [CrossRef] [PubMed]

42. Mohammed, M.J.; Al-Bayati, F.A. Isolation and identification of antibacterial compounds from Thymus kotschyanus aerial parts and Dianthus caryophyllus flower buds. Phytomedicine 2009, 16, 632-637. [CrossRef]

43. Sousa, A.F.; Vilela, C.; Fonseca, A.C.; Gruter, G.J.M.; Coelho, J.F.J.; Silvestre, A.J.D.; Matos, M.; Freire, C.S.R. Biobased polyesters and other polymers from 2,5-furandicarboxylic acid: A tribute to furan excellency. Polym. Chem. 2015, 6, 5961-5983. [CrossRef]

44. Sadler, J.M.; Toulan, F.R.; Nguyen, A.P.T.; Kayea III, R.V.; Ziaee, S.; Palmese, G.R.; La Scala, J.J. Isosorbide as the structural component of bio-based unsaturated polyesters for use as thermosetting resins. Carbohydr. Polym. 2014, 100, 97-106. [CrossRef]

45. Ma, S.; Liu, X.; Jiang, Y.; Fan, L.; Feng, J.; Zhu, J. Synthesis and properties of phosphorus-containing bio-based epoxy resin from itaconic acid. Sci. China Chem. 2014, 57, 379-388. [CrossRef]

46. Willke, T.; Vorlop, K.-D. Biotechnological production of itaconic acid. Appl. Microbiol. Biotechnol. 2001, 56, 289-295. [CrossRef] 
47. Ghaffar, T.; Irshad, M.; Anwar, Z.; Aqil, T.; Zulifqar, Z.; Tariq, A.; Kamran, M.; Ehsan, N.; Mehmood, S. Recent trends in lactic acid biotechnology: A brief review on production to purification. J. Radiat. Res. Appl. Sci. 2014, 7, 222-229. [CrossRef]

48. Wazarkar, K.; Kathalewar, M.; Sabnis, A. Reactive Modification of Thermoplastic and Thermoset Polymers using Flame Retardants: An Overview. Polym. Plast. Technol. Eng. 2016, 55, 71-91. [CrossRef]

49. Van Es, D.S.; Van der Klis, F.; Van Haveren, J. Succinic Acid from Biomass. U.S. Patent WO 2012044168, 5 May 2012.

50. Girisuta, B. Levulinic Acid from Lignocellulosic Biomass. Ph.D. Thesis, University of Groningen, Groningen, The Netherlands, 2007.

51. Prieur, B.; Meub, M.; Wittemann, M.; Klein, R.; Bellayer, S.; Fontaine, G.; Bourbigot, S. Phosphorylation of lignin: Characterization and investigation of the thermal decomposition. RSC Adv. 2017, 7, 16866-16877. [CrossRef]

52. Prieur, B.; Meub, M.; Wittemann, M.; Klein, R.; Bellayer, S.; Fontaine, G.; Bourbigot, S. Phosphorylation of lignin to flame retard acrylonitrile butadiene styrene (ABS). Polym. Degrad. Stab. 2016, 127, 32-43. [CrossRef]

53. Ferry, L.; Dorez, G.; Taguet, A.; Otazaghine, B.; Lopez-Cuesta, J. Chemical modification of lignin by phosphorus molecules to improve the fire behavior of polybutylene succinate. Polym. Degrad. Stab. 2015, 113, 135-143. [CrossRef]

54. Fache, M.; Boutevin, B.; Caillol, S. Vanillin, a key-intermediate of biobased polymers. Eur. Polym. J. 2015, 68, 488-502. [CrossRef]

55. Laskar, D.D.; Yang, B.; Wang, H.; Lee, J. Pathways for biomass-derived lignin to hydrocarbon fuels. Biofuels, Bioprod. Biorefining 2013, 7, 602-626. [CrossRef]

56. Taing, O.; Taing, K. Production of malic and succinic acids by sugar-tolerant yeast Zygosaccharomyces rouxii. Eur. Food Res. Technol. 2007, 224, 343-347. [CrossRef]

57. Yang, X.; Wang, C.; Xia, J.; Mao, W.; Li, S. Study on synthesis of novel phosphorus-containing flame retardant epoxy curing agents from renewable resources and the comprehensive properties of their combined cured products. Prog. Org. Coatings 2017, 110, 195-203. [CrossRef]

58. Kim, E.-M.; Eom, J.-H.; Um, Y.; Kim, Y.; Woo, H.M. Microbial Synthesis of Myrcene by Metabolically Engineered Escherichia coli. J. Agric. Food Chem. 2015, 63, 4606-4612. [CrossRef]

59. Behr, A.; Johnen, L. Myrcene as a Natural Base Chemical in Sustainable Chemistry: A Critical Review. ChemSusChem 2009, 12, 1072-1095. [CrossRef]

60. Lligadas, G.; Ronda, J.C.; Galià, M.; Cádiz, V. Development of novel phosphorus-containing epoxy resins from renewable resources. J. Polym. Sci. Part A Polym. Chem. 2006, 44, 6717-6727. [CrossRef]

61. Ran, N.; Knop, D.R.; Draths, K.M.; Frost, J.W. Benzene-Free Synthesis of Hydroquinone. J. Am. Chem. Soc. 2001, 123, 10927-10934. [CrossRef] [PubMed]

62. Ménard, R.; Fache, M.; Negrell, C.; Ferry, L.; Sonnier, R.; David, G. From a bio-based phosphorus-containing epoxy monomer to fully bio-based flame-retardant thermosets. RSC Adv. 2015, 5, 70856-70867. [CrossRef]

63. Glombitza, K.-W. Highly Hydroxylated Phenols of the Phaeophyceae. In Marine Natural Products Chemistry; Springer Science: Boston, MA, USA, 1977; pp. 191-204.

64. Zhang, T.; Yan, H.; Shen, L.; Fang, Z.; Zhang, X.; Wang, J.; Zhang, B. Chitosan/Phytic Acid Polyelectrolyte Complex: A Green and Renewable Intumescent Flame Retardant System for Ethylene-Vinyl Acetate Copolymer. Ind. Eng. Chem. Res. 2014, 53, 19199-19207. [CrossRef]

65. Cheng, X.-W.; Guan, J.-P.; Tang, R.-C.; Liu, K.-Q. Phytic acid as a bio-based phosphorus flame retardant for poly(lactic acid) nonwoven fabric. J. Clean. Prod. 2016, 124, 114-119. [CrossRef]

66. Lolas, G.M.; Markakis, P. Phytic acid and other phosphorus compounds of beans (Phaseolus vulgaris L.). J. Agric. Food Chem. 1975, 23, 13-15. [CrossRef]

67. Kraus, G.A. Synthetic Methods for the Preparation of 1,3-Propanediol. CLEAN Soil Air Water 2008, 36, 648-651. [CrossRef]

68. Ogunniyi, D. Castor oil: A vital industrial raw material. Bioresour. Technol. 2006, 97, 1086-1091. [CrossRef]

69. Wang, X.L.; Chen, L.; Wu, J.N.; Fu, T.; Wang, Y.Z. Flame-Retardant Pressure-Sensitive Adhesives Derived from Epoxidized Soybean Oil and Phosphorus-Containing Dicarboxylic Acids. ACS Sustain. Chem. Eng. 2017, 5, 3353-3361. [CrossRef]

70. Barrow, K.; Collins, J.; Leight, D.; Rogers, P.; Warr, R. Sorbitol production by Zymomonas mobilis. Appl. Microbiol. Biotechnol. 1984, 20, 225-232. [CrossRef] 
71. Ladero, V.; Ramos, A.; Wiersma, A.; Goffin, P.; Schanck, A.; Kleerebezem, M.; Hugenholtz, J.; Smid, E.J.; Hols, P. High-Level Production of the Low-Calorie Sugar Sorbitol by Lactobacillus plantarum through Metabolic Engineering. Appl. Environ. Microbiol. 2007, 73, 1864-1872. [CrossRef] [PubMed]

72. Pinazo, J.M.; Domine, M.E.; Parvulescu, V.; Petru, F. Sustainability metrics for succinic acid production: A comparison between biomass-based and petrochemical routes. Catal. Today 2015, 239, 17-24. [CrossRef]

73. Dhamaniya, S.; Jacob, J. Synthesis and characterization of polyesters based on tartaric acid derivatives. Polymer 2010, 51, 5392-5399. [CrossRef]

74. Howell, B.A.; Carter, K.E.; Dangalle, H. Flame Retardants Based on Tartaric Acid: A Renewable By-Product of the Wine Industry. In ACS Symposium Series; American Chemical Society (ACS): Washington, DC, USA, 2011; Volume 1063, pp. 133-152.

75. Collias, D.I.; Harris, A.M.; Nagpal, V.; Cottrell, I.W.; Schultheis, M.W. Biobased Terephthalic Acid Technologies: A Literature Review. Ind. Biotechnol. 2014, 10, 91-105. [CrossRef]

76. Tachibana, Y.; Kimura, S.; Kasuya, K.-I. Synthesis and Verification of Biobased Terephthalic Acid from Furfural. Sci. Rep. 2015, 5, 8249. [CrossRef] [PubMed]

77. Araújo, J.D.; Grande, C.A.; Rodrigues, A.E. Vanillin production from lignin oxidation in a batch reactor. Chem. Eng. Res. Des. 2010, 88, 1024-1032. [CrossRef]

78. Amarasekara, A.S.; Wiredu, B.; Razzaq, A. Vanillin based polymers: I. An electrochemical route to polyvanillin. Green Chem. 2012, 14, 2395. [CrossRef]

79. Fourcade, D.; Ritter, B.S.; Walter, P.; Schönfeld, R.; Mülhaupt, R. Renewable resource-based epoxy resins derived from multifunctional poly(4-hydroxybenzoates). Green Chem. 2013, 15, 910. [CrossRef]

80. Camino, G.; Costa, L.; Trossarelli, L. Study of the mechanism of intumescence in fire retardant polymers: Part I-Thermal degradation of ammonium polyphosphate-pentaerythritol mixtures. Polym. Degrad. Stab. 1984, 6, 243-252. [CrossRef]

81. Bourbigot, S.; Le Bras, M.; Delobel, R. Carbonization mechanisms resulting from intumescence association with the ammonium polyphosphate-pentaerythritol fire retardant system. Carbon 1993, 31, 1219-1230. [CrossRef]

82. Wang, Z.; Lv, P.; Hu, Y.; Hu, K. Thermal degradation study of intumescent flame retardants by TG and FTIR: Melamine phosphate and its mixture with pentaerythritol. J. Anal. Appl. Pyrolysis 2009, 86, 207-214. [CrossRef]

83. Tao, K.; Li, J.; Xu, L.; Zhao, X.; Xue, L.; Fan, X.; Yan, Q. A novel phosphazene cyclomatrix network polymer: Design, synthesis and application in flame retardant polylactide. Polym. Degrad. Stab. 2011, 96, 1248-1254. [CrossRef]

84. Zhan, J.; Song, L.; Nie, S.; Hu, Y. Combustion properties and thermal degradation behavior of polylactide with an effective intumescent flame retardant. Polym. Degrad. Stab. 2009, 94, 291-296. [CrossRef]

85. Xuan, S.; Wang, X.; Song, L.; Xing, W.; Lu, H.; Hu, Y. Study on flame-retardancy and thermal degradation behaviors of intumescent flame-retardant polylactide systems. Polym. Int. 2011, 60, 1541-1547. [CrossRef]

86. Tang, X.; Jing, J.; Zhang, Y.; Fang, Z. Synthesis of a highly efficient phosphorus-containing flame retardant utilizing plant-derived diphenolic acids and its application in polylactic acid. RSC Adv. 2016, 6, 49019-49027.

87. Bozell, J.J.; Moens, L.; Elliott, D.; Wang, Y.; Neuenscwander, G.; Fitzpatrick, S.; Bilski, R.; Jarnefeld, J. Production of levulinic acid and use as a platform chemical for derived products. Resour. Conserv. Recycl. 2000, 28, 227-239. [CrossRef]

88. Zhao, P.; Liu, Z.; Wang, X.; Pan, Y.T.; Kuehnert, I.; Gehde, M.; Wang, D.-Y.; Leuteritz, A. Renewable vanillin based flame retardant for poly(lactic acid): A way to enhance flame retardancy and toughness simultaneously. RSC Adv. 2018, 8, 42189-42199. [CrossRef]

89. Lin, H.J.; Liu, S.R.; Han, L.J.; Wang, X.M.; Bian, Y.J.; Dong, L.S. Effect of a phosphorus-containing oligomer on flame-retardant, rheological and mechanical properties of poly (lactic acid). Polym. Degrad. Stab. 2013, 98, 1389-1396. [CrossRef]

90. Wang, D.Y.; Song, Y.P.; Lin, L.; Wang, X.L.; Wang, Y.Z. A novel phosphorus-containing poly(lactic acid) toward its flame retardation. Polymer 2011, 52, 233-238. [CrossRef]

91. Yu, S.; Xiang, H.; Zhou, J.; Zhu, M. Enhanced flame-retardant performance of poly (lactic acid)(PLA) composite by using intrinsically phosphorus-containing PLA. Prog. Nat. Sci. 2018, 28, 590-597. [CrossRef] 
92. Fenouillot, F.; Rousseau, A.; Colomines, G.; Saint-Loup, R.; Pascault, J.-P. Polymers from renewable 1,4:3,6-dianhydrohexitols (isosorbide, isomannide and isoidide): A review. Prog. Polym. Sci. 2010, 35, 578-622. [CrossRef]

93. Fletcher, H.G.; Goepp, R.M. Hexitol Anhydrides.11,4,3,6-Dianhydro-L-iditol and the Structures of Isomannide and Isosorbide. J. Am. Chem. Soc. 1946, 68, 939-941. [CrossRef] [PubMed]

94. Flèche, G.; Huchette, M. Isosorbide. Preparation, Properties and Chemistry. Starch Stärke 1986, 38, 26-30. [CrossRef]

95. Daniel, Y.G.; Howell, B.A. Synthesis and characterization of isosorbide bis -phosphorus esters. Heteroat. Chem. 2017, 28, e21369. [CrossRef]

96. Mauldin, T.C.; Zammarano, M.; Gilman, J.W.; Shields, J.R.; Boday, D.J. Synthesis and characterization of isosorbide-based polyphosphonates as biobased flame-retardants. Polym. Chem. 2014, 5, 5139. [CrossRef]

97. Hu, C.; Bourbigot, S.; Delaunay, T.; Collinet, M.; Marcille, S.; Fontaine, G. Synthesis of isosorbide based flame retardants: Application for polybutylene succinate. Polym. Degrad. Stab. 2019, 164, 9-17. [CrossRef]

98. Daniel, Y.G.; Howell, B.A. Flame retardant properties of isosorbide bis -phosphorus esters. Polym. Degrad. Stab. 2017, 140, 25-31. [CrossRef]

99. Zhang, R.; Xiao, X.; Tai, Q.; Huang, H.; Hu, Y. Modification of lignin and its application as char agent in intumescent flame-retardant poly(lactic acid). Polym. Eng. Sci. 2012, 12, 2620-2626. [CrossRef]

100. De Carvalho, J.C.; Magalhaes, A.I.; Soccol, C.R. Biobased itaconic acid market and research trends-Is it really a promising chemical. Chim. Oggi Chem. Today 2018, 36, 56-58.

101. Pospiech, D.; Korwitz, A.; Komber, H.; Jehnichen, D.; Häußler, L.; Scheibner, H.; Liebmann, M.; Jähnichen, K.; Voit, B. Biobased Aliphatic Polyesters with DOPO Substituents for Enhanced Flame Retardancy. Macromol. Chem. Phys. 2015, 216, 1447-1461. [CrossRef]

102. Sonnier, R.; Taguet, A.; Ferry, L.; Lopez-Cuesta, J.M. Towards Bio-based Flame Retardant Polymers; Springer: New York, NY, USA, 2018.

103. Xie, M.; Zhang, S.; Ding, Y.; Wang, F.; Liu, P.; Tang, H.; Wang, Y.; Yang, M. Synthesis of a heat-resistant DOPO derivative and its application as flame-retardant in engineering plastics. J. Appl. Polym. Sci. 2017, 134, 134. [CrossRef]

104. Salmeia, K.A.; Gooneie, A.; Simonetti, P.; Nazir, R.; Kaiser, J.-P.; Rippl, A.; Hirsch, C.; Lehner, S.; Rupper, P.; Hufenus, R.; et al. Comprehensive study on flame retardant polyesters from phosphorus additives. Polym. Degrad. Stab. 2018, 155, 22-34. [CrossRef]

105. Carosio, F.; Cuttica, F.; Di Blasio, A.; Alongi, J.; Malucelli, G. Layer by layer assembly of flame retardant thin films on closed cell PET foams: Efficiency of ammonium polyphosphate versus DNA. Polym. Degrad. Stab. 2015, 113, 189-196. [CrossRef]

106. Zhang, Y.; Yu, B.; Wang, B.; Liew, K.M.; Song, L.; Wang, C.; Hu, Y. Highly Effective P-P Synergy of a Novel DOPO-Based Flame Retardant for Epoxy Resin. Ind. Eng. Chem. Res. 2017, 56, 1245-1255. [CrossRef]

107. Alongi, J.; Cuttica, F.; Carosio, F. DNA coatings from byproducts: A panacea for the flame retardancy of EVA, PP, ABS, PET, and PA6? ACS Sustain. Chem. Eng. 2016, 4, 3544-3551. [CrossRef]

108. Alongi, J.; Milnes, J.; Malucelli, G.; Bourbigot, S.; Kandola, B. Thermal degradation of DNA-treated cotton fabrics under different heating conditions. J. Anal. Appl. Pyrolysis 2014, 108, 212-221. [CrossRef]

109. Carosio, F.; Di Blasio, A.; Alongi, J.; Malucelli, G. Green DNA-based flame retardant coatings assembled through Layer by Layer. Polymer 2013, 54, 5148-5153. [CrossRef]

110. Alongi, J.; Carletto, R.A.; Di Blasio, A.; Cuttica, F.; Carosio, F.; Bosco, F.; Malucelli, G. Intrinsic intumescent-like flame retardant properties of DNA-treated cotton fabrics. Carbohydr. Polym. 2013, 96, 296-304. [CrossRef]

111. Alongi, J.; Carletto, R.A.; Di Blasio, A.; Carosio, F.; Bosco, F.; Malucelli, G. DNA: A novel, green, natural flame retardant and suppressant for cotton. J. Mater. Chem. A 2013, 1, 4779. [CrossRef]

112. Malucelli, G. 9 Textile Finishing with Biomacromolecules: A low Environmental Impact Approach in Flame Retardancy. In The Impact and Prospects of Green Chemistry for Textile Technology; Shahid ul, I., Butola, B.S., Eds.; Woodhead Publishing: Sawston/Cambridge, UK, 2019; pp. 251-279. ISBN 978-0-08-102491-1.

113. Carosio, F.; Di Blasio, A.; Cuttica, F.; Alongi, J.; Malucelli, G. Flame Retardancy of Polyester and Polyester-Cotton Blends Treated with Caseins. Ind. Eng. Chem. Res. 2014, 53, 3917-3923. [CrossRef]

114. Alongi, J.; Carletto, R.A.; Bosco, F.; Carosio, F.; Di Blasio, A.; Cuttica, F.; Antonucci, V.; Giordano, M.; Malucelli, G. Caseins and hydrophobins as novel green flame retardants for cotton fabrics. Polym. Degrad. Stab. 2014, 99, 111-117. [CrossRef] 
115. Richter, C.A.; Birnbaum, L.S.; Farabollini, F.; Newbold, R.R.; Rubin, B.S.; Talsness, C.E.; Vandenbergh, J.G.; Walser-Kuntz, D.R.; Saal, F.S.V. In vivo effects of bisphenol A in laboratory rodent studies. Reprod. Toxicol. 2007, 24, 199-224. [CrossRef] [PubMed]

116. Vom Saal, F.S.; Akingbemi, B.T.; Belcher, S.M.; Birnbaum, L.S.; Crain, D.A.; Eriksen, M.; Farabollini, F.; Guillette, L.J.; Hauser, R.; Heindel, J.J.; et al. Chapel Hill bisphenol A expert panel consensus statement: Integration of mechanisms, effects in animals and potential to impact human health at current levels of exposure. Reprod. Toxicol. 2007, 24, 131-138. [CrossRef] [PubMed]

117. Sullivan, A.W.; Beach, E.C.; Stetzik, L.A.; Perry, A.; D'Addezio, A.S.; Cushing, B.S.; Patisaul, H.B. A Novel Model for Neuroendocrine Toxicology: Neurobehavioral Effects of BPA Exposure in a Prosocial Species, the Prairie Vole (Microtus ochrogaster). Endocrinology 2014, 155, 3867-3881. [CrossRef]

118. Auvergne, R.; Caillol, S.; David, G.; Boutevin, B.; Pascault, J.P. Biobased thermosetting epoxy: Present and future. Chem. Rev. 2014, 114, 1082-1115. [CrossRef]

119. Wan, J.; Gan, B.; Molina-Aldareguia, J.; Li, C.; Wang, X. A novel biobased epoxy resin with high mechanical stiffness and low flammability: Synthesis, characterization and properties. J. Mater. Chem. A 2015, 3, 21907-21921. [CrossRef]

120. Dai, J.; Peng, Y.; Teng, N.; Liu, Y.; Liu, C.; Shen, X.; Mahmud, S.; Zhu, J.; Liu, X. High-Performing and Fire-Resistant Biobased Epoxy Resin from Renewable Sources. ACS Sustain. Chem. Eng. 2018, 6, 7589-7599. [CrossRef]

121. Liggins, J.; Bluck, L.J.; Runswick, S.; Atkinson, C.; Coward, W.; Bingham, S.A. Daidzein and genistein content of fruits and nuts. J. Nutr. Biochem. 2000, 11, 326-331. [CrossRef]

122. Ma, S.; Liu, X.; Jiang, Y.; Tang, Z.; Zhang, C.; Zhu, J. Bio-based epoxy resin from itaconic acid and its thermosets cured with anhydride and comonomers. Green Chem. 2012, 15, 245-254. [CrossRef]

123. Szolnoki, B.; Toldy, A.; Konrad, P.; Szebényi, G.; Marosi, G. Comparison of additive and reactive phosphorus-based flame retardants in epoxy resins. Period. Polytech. Chem. Eng. 2013, 57, 85. [CrossRef]

124. Tsujimoto, T.; Uyama, H.; Kobayashi, S. Green Nanocomposites from Renewable Resources: Biodegradable Plant Oil-Silica Hybrid Coatings. Macromol. Rapid Commun. 2003, 24, 711-714. [CrossRef]

125. Lligadas, G.; Ronda, J.C.; Galià, M.; Cádiz, V. Synthesis and properties of thermosetting polymers from a phosphorous-containing fatty acid derivative. J. Polym. Sci. Part A Polym. Chem. 2006, 44, 5630-5644. [CrossRef]

126. Koeduka, T.; Fridman, E.; Gang, D.R.; Vassão, D.G.; Jackson, B.L.; Kish, C.M.; Orlova, I.; Spassova, S.M.; Lewis, N.G.; Noel, J.P.; et al. Eugenol and isoeugenol, characteristic aromatic constituents of spices, are biosynthesized via reduction of a coniferyl alcohol ester. Proc. Natl. Acad. Sci. USA 2006, 103, 10128-10133. [CrossRef] [PubMed]

127. Calo, E.; Maffezzoli, A.; Mele, G.; Martina, F.; Mazzetto, S.E.; Tarzia, A.; Stifani, C. Synthesis of a novel cardanol-based benzoxazine monomer and environmentally sustainable production of polymers and bio-composites. Green Chem. 2007, 9, 754. [CrossRef]

128. Mallikappa, D.; Reddy, R.P.; Murthy, C. Performance and emission characteristics of double cylinder CI engine operated with cardanol bio fuel blends. Renew. Energy 2012, 38, 150-154. [CrossRef]

129. Menon, A.R.R.; Pillai, C.K.S.; Nando, G.B. Chemical crosslink densit and network structure of natural rubber vulcanizates modified with phosphorylated cardnol prepolymer. J. Appl. Polym. Sci. 1994, 51, 2157-2164. [CrossRef]

130. Antony, R.; Pillai, C.K.S.; Scariah, K.J. GPC studies on the cationic polymerization of cardanol initiated by borontrifluoridediethyletherate. J. Appl. Polym. Sci. 1990, 41, 1765-1775. [CrossRef]

131. John, G.; Masuda, M.; Okada, Y.; Yase, K.; Shimizu, T. Nanotube Formation from Renewable Resources via Coiled Nanofibers. Adv. Mater. 2001, 13, 715-718. [CrossRef]

132. Saladino, R.; Neri, V.; Mincione, E.; Marini, S.; Coletta, M.; Fiorucci, C.; Filippone, P. A new and efficient synthesis of ortho- and para-benzoquinones of cardanol derivatives by the catalytic system MeReO3-H2O2. J. Chem. Soc. Perkin Trans. 2000, 1, 581-586. [CrossRef]

133. Toldy, A.; Szolnoki, B.; Csontos, I.; Marosi, G. Green synthesis and characterization of phosphorus flame retardant crosslinking agents for epoxy resins. J. Appl. Polym. Sci. 2014, 131. [CrossRef]

134. Abell, J.P.; Yamamoto, H. Catalytic Enantioselective Pudovik Reaction of Aldehydes and Aldimines with Tethered Bis(8-quinolinato) (TBOx) Aluminum Complex. J. Am. Chem. Soc. 2008, 130, 10521-10523. [CrossRef] [PubMed] 
135. Xie, C.; Zeng, B.; Gao, H.; Xu, Y.; Luo, W.; Liu, X.; Dai, L. Improving thermal and flame-retardant properties of epoxy resins by a novel reactive phosphorous-containing curing agent. Polym. Eng. Sci. 2014, 54, 1192-1200. [CrossRef]

136. Lin, C.H.; Chou, Y.C.; Shiao, W.F.; Wang, M.W. High temperature, flame-retardant, and transparent epoxy thermosets prepared from an acetovanillone-based hydroxyl poly(ether sulfone) and commercial epoxy resins. Polymer 2016, 97, 300-308. [CrossRef]

137. Lin, C.M.; Chen, C.H.; Lin, C.H.; Juang, T.Y. High-performance bio-based benzoxazines derived from phosphinated biphenols and furfurylamine. Eur. Polym. J. 2018, 108, 48-56. [CrossRef]

138. Wang, X.; Hu, Y.; Song, L.; Yang, H.; Xing, W.; Lu, H. Synthesis and characterization of a DOPO-substitued organophosphorus oligomer and its application in flame retardant epoxy resins. Prog. Org. Coatings 2011, 71, 72-82. [CrossRef]

139. Yang, X.; Li, S.; Xia, J.; Song, J.; Huang, K.; Li, M. Novel renewable resource-based UV-curable copolymers derived from myrcene and tung oil: Preparation, characterization and properties. Ind. Crops Prod. 2015, 63, 17-25. [CrossRef]

140. Chen, H.B.; Dong, X.; Schiraldi, D.A.; Chen, L.; Wang, D.Y.; Wang, Y.Z. Phosphorus-containing poly(trimethylene terephthalate) derived from 2-(6-oxido-6H-dibenz $<$ c,e $><1,2>$ oxaphosphorin-6-yl)1,4-hydroxyethoxy phenylene: Synthesis, thermal degradation, combustion and pyrolysis behavior. J. Anal. Appl. Pyrolysis 2013, 99, 40-48. [CrossRef]

141. Li, T.; Shi, Z.; He, X.; Jiang, P.; Lu, X.; Zhang, R.; Wang, X. Aging-Resistant Functionalized LDH-SAS/Nitrile-Butadiene Rubber Composites: Preparation and Study of Aging Kinetics/Anti-Aging Mechanism. Materials 2018, 11, 836. [CrossRef]

142. Schmidt, C.; Ciesielski, M.; Greiner, L.; Döring, M. Novel organophosphorus flame retardants and their synergistic application in novolac epoxy resin. Polym. Degrad. Stab. 2018, 158, 190-201. [CrossRef]

143. Wang, P.J.; Liao, D.J.; Hu, X.P.; Pan, N.; Li, W.X.; Wang, D.Y.; Yao, Y. Facile fabrication of biobased P N C-containing nano-layered hybrid: Preparation, growth mechanism and its efficient fire retardancy in epoxy. Polym. Degrad. Stab. 2019, 159, 153-162. [CrossRef]

144. Graf, E. Antioxidant functions of phytic acid. Free. Radic. Biol. Med. 1990, 8, 61-69. [CrossRef]

145. Zhao, X.; Xiao, D.; Alonso, J.P.; Wang, D.Y. Inclusion complex between beta-cyclodextrin and phenylphosphonicdiamide as novel bio-based flame retardant to epoxy: Inclusion behavior, characterization and flammability. Mater. Des. 2017, 114, 623-632. [CrossRef]

146. Zhao, X.; Yang, L.; Martin, F.H.; Zhang, X.Q.; Wang, R.; Wang, D.Y. Influence of phenylphosphonate based flame retardant on epoxy/glass fiber reinforced composites (GRE): Flammability, mechanical and thermal stability properties. Compos. Part B Eng. 2017, 110, 511-519. [CrossRef]

147. Fache, M.; Darroman, E.; Besse, V.; Auvergne, R.; Caillol, S.; Boutevin, B. Vanillin, a promising biobased building-block for monomer synthesis. Green Chem. 2014, 16, 1987-1998. [CrossRef]

148. Jin, S.; Qian, L.; Qiu, Y.; Chen, Y.; Xin, F. High-efficiency flame retardant behavior of bi-DOPO compound with hydroxyl group on epoxy resin. Polym. Degrad. Stab. 2019, 166, 344-352. [CrossRef]

149. Lehr, V.; Sarlea, M.; Ott, L.; Vogel, H. Catalytic dehydration of biomass-derived polyols in sub- and supercritical water. Catal. Today 2007, 121, 121-129. [CrossRef]

150. Howell, B.A.; Sun, W. Biobased flame retardants from tartaric acid and derivatives. Polym. Degrad. Stab. 2018, 157, 199-211. [CrossRef]

151. Mehta, R.; Kumar, V.; Bhunia, H.; Upadhyay, S.N. Synthesis of Poly(Lactic Acid): A Review. J. Macromol. Sci. Part C 2005, 45, 325-349. [CrossRef]

152. Domenek, S.; Courgneau, C.; Ducruet, V. Characteristics and Applications of Poly(lactide). Biopolymers 2011, 183-223.

153. Obuchi, S.; Ogawa, S. Packaging and Other Commercial Applications. Poly (Lactic Acid) 2010, 457-467.

154. Hamad, K. Properties and medical applications of polylactic acid: A review. Express Polym. Lett. 2015, 9, 435-455. [CrossRef]

155. Bourbigot, S.; Fontaine, G. Flame retardancy of polylactide: An overview. Polym. Chem. 2010, 1, 1413. [CrossRef]

156. Chow, W.; Teoh, E.; Karger-Kocsis, J. Flame retarded poly(lactic acid): A review. eXPRESS Polym. Lett. 2018, 12, 396-417. [CrossRef]

157. Tawiah, B.; Yu, B.; Fei, B. Advances in Flame Retardant Poly(Lactic Acid). Polymers 2018, 10, 876. [CrossRef] 
158. Jing, J.; Zhang, Y.; Tang, X.; Li, X.; Peng, M.; Fang, Z. Combination of a bio-based polyphosphonate and modified graphene oxide toward superior flame retardant polylactic acid. RSC Adv. 2018, 8, 4304-4313. [CrossRef]

159. Lin, H.; Han, L.; Dong, L. Thermal degradation behavior and gas phase flame-retardant mechanism of polylactide/PCPP blends. J. Appl. Polym. Sci. 2014, 131, 131. [CrossRef]

160. Réti, C.; Casetta, M.; Duquesne, S.; Bourbigot, S.; Delobel, R. Flammability properties of intumescent PLA including starch and lignin. Polym. Adv. Technol. 2008, 19, 628-635. [CrossRef]

161. Costes, L.; Laoutid, F.; Aguedo, M.; Richel, A.; Brohez, S.; Delvosalle, C.; Dubois, P. Phosphorus and nitrogen derivatization as efficient route for improvement of lignin flame retardant action in PLA. Eur. Polym. J. 2016, 84, 652-667. [CrossRef]

162. Costes, L.; Laoutid, F.; Brohez, S.; Delvosalle, C.; Dubois, P. Phytic acid-lignin combination: A simple and efficient route for enhancing thermal and flame retardant properties of polylactide. Eur. Polym. J. 2017, 94, 270-285. [CrossRef]

163. Costes, L.; Laoutid, F.; Dumazert, L.; Lopez-Cuesta, J.-M.; Brohez, S.; Delvosalle, C.; Dubois, P. Metallic phytates as efficient bio-based phosphorous flame retardant additives for poly(lactic acid). Polym. Degrad. Stab. 2015, 119, 217-227. [CrossRef]

164. Laoutid, F.; Vahabi, H.; Shabanian, M.; Aryanasab, F.; Zarrintaj, P.; Saeb, M.R. A new direction in design of bio-based flame retardants for poly(lactic acid). Fire Mater. 2018, 42, 914-924. [CrossRef]

165. Costes, L.; Laoutid, F.; Khelifa, F.; Rose, G.; Brohez, S.; Delvosalle, C.; Dubois, P. Cellulose/phosphorus combinations for sustainable fire retarded polylactide. Eur. Polym. J. 2016, 74, 218-228. [CrossRef]

166. Fox, D.M.; Lee, J.; Citro, C.J.; Novy, M. Flame retarded poly(lactic acid) using POSS-modified cellulose. 1. Thermal and combustion properties of intumescing composites. Polym. Degrad. Stab. 2013, 98, 590-596. [CrossRef]

167. Fox, D.M.; Novy, M.; Brown, K.; Zammarano, M.; Harris, R.H.; Murariu, M.; McCarthy, E.D.; Seppala, J.E.; Gilman, J.W. Flame retarded poly(lactic acid) using POSS-modified cellulose. 2. Effects of intumescing flame retardant formulations on polymer degradation and composite physical properties. Polym. Degrad. Stab. 2014, 106, 54-62. [CrossRef]

168. Vahabi, H.; Shabanian, M.; Aryanasab, F.; Mangin, R.; Laoutid, F.; Saeb, M.R. Inclusion of modified lignocellulose and nano-hydroxyapatite in development of new bio-based adjuvant flame retardant for poly(lactic acid). Thermochim. Acta 2018, 666, 51-59. [CrossRef]

169. Chen, C.; Gu, X.; Jin, X.; Sun, J.; Zhang, S. The effect of chitosan on the flammability and thermal stability of polylactic acid/ammonium polyphosphate biocomposites. Carbohydr. Polym. 2017, 157, 1586-1593. [CrossRef]

170. Feng, J.X.; Su, S.P.; Feng, J.; Su, S.; Zhu, J. An intumescent flame retardant system using $\beta$-cyclodextrin as a carbon source in polylactic acid (PLA). Polym. Adv. Technol. 2011, 22, 1115-1122. [CrossRef]

171. Wang, X.; Xing, W.; Wang, B.; Wen, P.; Song, L.; Hu, Y.; Zhang, P. Comparative Study on the Effect of Beta-Cyclodextrin and Polypseudorotaxane As Carbon Sources on the Thermal Stability and Flame Retardance of Polylactic Acid. Ind. Eng. Chem. Res. 2013, 52, 3287-3294. [CrossRef]

172. Wang, X.; Hu, Y.; Song, L.; Xuan, S.; Xing, W.; Bai, Z.; Lu, H. Flame Retardancy and Thermal Degradation of Intumescent Flame Retardant Poly(lactic acid)/Starch Biocomposites. Ind. Eng. Chem. Res. 2011, 50, 713-720. [CrossRef]

173. Zhang, S.; Jin, X.; Gu, X.; Chen, C.; Li, H.; Zhang, Z.; Sun, J. The preparation of fully bio-based flame retardant poly(lactic acid) composites containing casein. J. Appl. Polym. Sci. 2018, 135, 46599. [CrossRef]

174. Zhang, N.; Shen, J.; Pasquinelli, M.A.; Hinks, D.; Tonelli, A.E. Formation and characterization of an inclusion complex of triphenyl phosphate and $\beta$-cyclodextrin and its use as a flame retardant for polyethylene terephthalate. Polym. Degrad. Stab. 2015, 120, 244-250. [CrossRef]

175. Fang, Y.; Liu, X.; Tao, X. Intumescent flame retardant and anti-dripping of PET fabrics through layer-by-layer assembly of chitosan and ammonium polyphosphate. Prog. Org. Coatings 2019, 134, 162-168. [CrossRef]

176. Stelzig, T.; Bommer, L.; Gaan, S.; Buczko, A. DOPO-Based Hybrid Flame Retardants. U.S. Patents 20170081590A1, 23 March 2017.

177. Seiji, E.; Takao, K.; Akitada, O.; Tatsuhiko, S.; Tadashi, I. Neue phosphor-enthaltende verbindungen. U.S. Patent C07F9/657172, 13 October 1976.

178. Wermter, H.; Futterer, T.; Fünderich, S. Flame Retardant Composition for Thermoplastic Molding Compounds. U.S. Patents 20120322923A1, 20 December 2012. 
179. LeComte, H.A.; Liggat, J.J. Commercial fire-retarded PET formulations-Relationship between thermal degradation behaviour and fire-retardant action. Polym. Degrad. Stab. 2008, 93, 498-506. [CrossRef]

180. Oliveira, J.T.; Correlo, V.M.; Sol, P.C.; Costa-Pinto, A.R.; Malafaya, P.B.; Salgado, A.J.; Bhattacharya, M.; Charbord, P.; Neves, N.M.; Reis, R.L. Assessment of the suitability of chitosan/polybutylene succinate scaffolds seeded with mouse mesenchymal progenitor cells for a cartilage tissue engineering approach. Tissue Eng. Part A 2008, 14, 1651-1661. [CrossRef]

181. Petchwattana, N.; Covavisaruch, S.; Wibooranawong, S.; Naknaen, P. Antimicrobial food packaging prepared from poly(butylene succinate) and zinc oxide. Measurement 2016, 93, 442-448. [CrossRef]

182. Fujimaki, T. Processability and properties of aliphatic polyesters, 'BIONOLLE', synthesized by polycondensation reaction. Polym. Degrad. Stab. 1998, 59, 209-214. [CrossRef]

183. Miao, J.-T.; Yuan, L.; Guan, Q.; Liang, G.; Gu, A. Biobased epoxy resin derived from eugenol with excellent integrated performance and high renewable carbon content. Polym. Int. 2018, 67, 1194-1202. [CrossRef]

184. Weibin, C.; Jianqing, Z.; Xuehao, L. Analysis of Standard Situation of PSA Tapes in China and Abroad. Sci. J. Chem. 2018, 6, 24. [CrossRef]

(C) 2019 by the authors. Licensee MDPI, Basel, Switzerland. This article is an open access article distributed under the terms and conditions of the Creative Commons Attribution (CC BY) license (http://creativecommons.org/licenses/by/4.0/). 